\title{
Patient related outcomes and improvements in quality of life following orthognathic surgery
}

DOI:

10.1111/ors. 12448

\section{Document Version}

Accepted author manuscript

Link to publication record in Manchester Research Explorer

\section{Citation for published version (APA):}

Dong, Q. N., \& Yates, J. M. (2020). Patient related outcomes and improvements in quality of life following orthognathic surgery. Oral Surgery, 13(1), 67-86. [https://doi.org/10.1111/ors.12448].

https://doi.org/10.1111/ors.12448

\section{Published in:}

Oral Surgery

\section{Citing this paper}

Please note that where the full-text provided on Manchester Research Explorer is the Author Accepted Manuscript or Proof version this may differ from the final Published version. If citing, it is advised that you check and use the publisher's definitive version.

\section{General rights}

Copyright and moral rights for the publications made accessible in the Research Explorer are retained by the authors and/or other copyright owners and it is a condition of accessing publications that users recognise and abide by the legal requirements associated with these rights.

\section{Takedown policy}

If you believe that this document breaches copyright please refer to the University of Manchester's Takedown Procedures [http://man.ac.uk/04Y6Bo] or contact uml.scholarlycommunications@manchester.ac.uk providing relevant details, so we can investigate your claim.

\section{OPEN ACCESS}


PROFESSOR JULIAN YATES (Orcid ID : 0000-0002-8187-023X)

Article type : Review

Title - Patient related outcomes and improvements in quality of life following orthognathic surgery

\section{Running title - Quality of life and orthognathic surgery}

Keywords: orthognathic surgery, facial deformity, operative outcomes, quality of life

Quang Dong ${ }^{1}$, Julian M. Yates ${ }^{2}$

${ }^{1}$ Department of Oral and Maxillofacial Surgery, Shimane University Faculty of Medicine

89-1 Enya-cho, Izumo 693-8501, Japan

${ }^{2}$ Faculty of Biology Medicine and Health, Division of Dentistry, J.R. Moore Building, University of Manchester, Oxford Road, Manchester, M13 9PL, United Kingdom

\section{Corresponding author}

Prof Julian M. Yates

Faculty of Biology Medicine and Health, Division of Dentistry, J.R. Moore Building, University of Manchester, Oxford Road, Manchester, M13 9PL, United Kingdom

Tel: +441612756865

E-mail: julian.yates@manchester.ac.uk

\section{Date of submission $-7^{\text {th }}$ May 2018}

This article has been accepted for publication and undergone full peer review but has not been through the copyediting, typesetting, pagination and proofreading process, which may lead to differences between this version and the Version of Record. Please cite this article as doi: 10.1111/ORS.12448

This article is protected by copyright. All rights reserved 


\begin{abstract}
Aim: The purpose of this systematic review is to summarise the findings evaluating changes in patient quality of life (QOL) following orthognathic surgery.
\end{abstract}

Material and Methods: On-line searches were undertaken to identify suitable studies. Prospective cohort or case-control studies using questionnaires or similar assessment instruments to evaluate preand post-orthognathic surgery QOL were included in the analysis. QOL was assessed in the following five domains: physical functioning and limitations, physical pain, psychological well-being and selfesteem, self-perception with regards to aesthetics, and social functioning and relationships.

Results: Of the 13 studies included in the analysis most noted significant improvements in all QOL domains. The domains in which the greatest improvements were noted postoperatively were psychological well-being and self-esteem and self-perception with regards to aesthetics. The results of the Short Form Health Survey (SF-36) revealed that patients experienced no considerable changes in QOL after orthognathic surgery, while the other assessment instruments used demonstrated that patients experienced changes primarily in self-perception within the aesthetics domain.

Conclusions: The results indicate that orthognathic surgery significantly improved QOL in the five domains detailed. In particular, surgery elicited the greatest improvements in QOL in the psychological well-being and self-esteem and self-perception in the aesthetics domains.

Clinical Relevance - Orthognathic surgery to address facial disharmony is not without its risks, some being significant. Therefore, an evaluation of the benefits of such surgery would be helpful to both patients and clinicians in order to make an informed decision. This review demonstrated that orthognathic surgery generally yields significant improvements in QOL in physical functioning and limitations, physical pain, psychological well-being and self-esteem, self-perception with regards to facial aesthetics, and social functioning and relationships. Psychological well-being and self-esteem and self-perception with regards to aesthetics were the two domains in which the greatest surgeryrelated benefits have been observed. 


\section{Introduction}

Orthognathic surgery encompasses a group of surgical procedures that are performed in conjunction with orthodontic treatment to improve functional and aesthetic defects caused by facial and dental disproportion. Orthognathic surgery was introduced more than 100 years ago, and the first mandibular osteotomy was described by Hullihen in $1849 .{ }^{1}$ Orthognathic surgery comprise procedures involving the maxilla, mandible, or both and may be used to treat a wide variety of abnormalities, including class II and class III skeletal or dental abnormalities, abnormal occlusions, cleft palate, and several types of facial asymmetry or facial disproportions.

The human face is a critical aesthetic area; thus, its appearance can have a major impact on a patient's physiological well-being, social interactions and overall quality of life (QOL). In some patients, even slight abnormalities can negatively influence QOL. ${ }^{2}$ By improving aesthetics, orthognathic surgery can play a crucial role in improving patients' self-esteem, as well as other QOLrelated factors. Additionally, functionality of the face and jaws or oral cavity is also important. Orthognathic surgery can correct a poor maxilla-mandible relationship, leading to improvements in chewing, biting and speech, which can substantially improve patient satisfaction and overall wellbeing. The relationships between aesthetic and functional deficiencies are complex and are often affected by multiple factors. Therefore, identifying the factors that contribute to general well-being is often difficult when attempting to determine the best means of improving patient QOL. Furthermore, it is important to have evidence of patient reported outcomes following elective surgical procedures, as this is essential when justifying healthcare funding, and also to inform patients of benefit.

Validated health related quality of life questionnaires have been used for many health related studies and have provided important information relating to patient outcomes, additionally they provide an opportunity to collate the findings.

Thus, several studies have assessed the impact of orthognathic surgery on patient QOL. The purpose of this systematic review is to summarise the findings of the most recent studies regarding changes in QOL after orthognathic surgery in the following five QOL domains: physical functioning and limitations, physical pain, psychological well-being and self-esteem, self-perception with regards to facial aesthetics, and social functioning and relationships.

This article is protected by copyright. All rights reserved 


\section{Material and Methods}

This systematic review was performed in accordance with the guidelines of the Preferred Reporting Items for Systematic Reviews and Meta-analyses (PRISMA) statement. ${ }^{3}$ The search protocol is shown in Figure 1.

\section{[Insert Figure 1 near here]}

\section{Search Strategy}

Studies eligible for inclusion in the analysis were identified through searches of MEDLINE (PubMed), Web of Science ('Surgery' and 'Dentistry Oral Surgery Medicine' categories), and Scopus. The aim of this review was to summarise the most recent studies regarding changes in QOL post-orthognathic surgery; thus, the searches were limited to studies published within the last 13 years, i.e., studies published from 2005-2018. The search was also restricted to English-language studies. The final PubMed search was conducted on Feb 1st, 2018, and the other searches were completed on Feb 2nd, 2018.

Information regarding the search strategies utilised within the above databases include the following terms used to search PubMed and Web of Science:

((Orthognathic surgery) OR (treat*) OR (Correction) OR (Le Fort I osteotomy) OR (BSSO) OR (bilateral sagittal split osteotomy) OR (maxillary advancement) OR (maxillary elongation) OR (maxillary impaction) OR (mandibular advancement) OR (mandibular set back) OR (bimaxillary osteotomy) OR (osteotomy) OR (surgical) OR (orthodontic-surgical)) AND ((dentofacial deformities) OR (class II) OR (class III) OR (malocclusion) OR (facial asymmetry) OR (facial deformities) OR (skeletal discrepancy) OR (skeletal discrepancies) OR (intermaxillary relationship) OR (intermaxillary relationship)) AND ((quality of life) OR (satisfaction) OR (questionnaire) OR (outcome) OR (perception) OR (well-being) OR (aesthetics) OR (esthetics) OR (appearance) OR (selfconsciousness) OR (function*) OR (awareness) OR (limitation) OR (psychological)).

A limited number of terms may be used in Scopus searches; thus, the following three separate groups of terms were used to search this database: ((orthognathic surgery) OR (treat*) OR (correction)) AND ((dentofacial deformities) OR (class II) OR (class III)) AND ((quality of life) OR 
(satisfaction)); ((Orthognathic surgery) OR (bilateral sagittal split osteotomy) OR (BSSO) OR (le fort I osteotomy)) AND ((facial asymmetry) OR (facial deformities) OR (skeletal discrepancy) OR (malocclusion) OR (occlusion)) AND ((quality of life) OR (perception)); and ((Orthognathic surgery) OR (advancement) OR (set back) OR (bimaxillary osteotomy) OR (osteotomy) OR (surgical)) AND ((deformities) OR (malocclusion) OR (occlusion)) AND ((quality of life) OR (questionnaire) OR (appearance) OR (psychological)).

\section{Inclusion and Exclusion Criteria}

Studies were included in this review if they were prospective cohort or case-control studies, involved patients who underwent maxillary and/or mandibular orthognathic surgery (with or without other surgical procedures) to correct facial disproportion causing functional and/or aesthetic problems, and used questionnaires or similar assessment instruments to assess patients' perceptions of their QOL before and after surgery. To be included in the analysis, each study must have evaluated healthy subjects without syndromic dentofacial deformities or systemic diseases who may or may not have undergone preoperative or postoperative orthodontic treatments. Eligible studies must also have assessed patient QOL in at least one of the following domains: physical functioning and limitations, physical pain, psychological well-being and self-esteem, self-perception with regards to facial aesthetics, and social functioning and relationships.

Studies including subjects who underwent distraction osteogenesis, as well as studies that failed to exclude patients who had psychological illnesses, cleft lip and/or palate, craniofacial syndromes, traumatic facial deformities, congenital malformations, or sleep apnoea, were excluded from the analysis.

\section{Study Selection}

Titles and abstracts of the studies were then screened and identified through the abovementioned online searches to eliminate studies that clearly did not meet the inclusion criteria. Subsequently the full-text versions of the remaining studies were evaluated to determine whether they met the inclusion/exclusion criteria. Duplicate studies were also excluded from the analysis. Study selection was performed independently by the authors, and discrepancies were resolved via discussion.

This article is protected by copyright. All rights reserved 


\section{Data Extraction}

The authors independently extracted data pertaining to the following items from each study: the author(s), year of publication, types of participants/inclusion criteria, participants' ages, exclusion criteria, types of QOL questionnaires or instruments used therein, QOL assessment schedules, types of data analyses, and outcomes. Discrepancies were resolved by discussion. If necessary, the study authors were contacted to obtain missing information.

\section{Critical Appraisal of the Included Studies}

Each study included in the analysis was critically appraised, as recommended in the Critical Appraisal Skills Programme (CASP) Cohort Study Checklist and CASP Case Control Checklist. ${ }^{4}$ The appraisal entailed the performance of assessments for selection bias, as well as bias resulting from differences in sample size, interventions, outcome measurements (appropriate use of questionnaires and timing of assessments), confounding factors, follow-up periods and assessment schedules. Study appraisal was also performed independently by the two authors, and disagreements were resolved via discussion.

\section{Results}

\section{Study Selection}

A total of 30,635 articles were retrieved through the above database searches. After excluding duplicate articles and removing studies that did not fulfil the inclusion criteria, we ultimately included 13 studies in this systematic review. Information regarding the study selection process is depicted in Figure 1.

\section{Study Characteristics}

The characteristics of the 13 included studies (involving 918 participants) are shown in Table 1. Twelve studies were prospective cohort studies, and one study was a prospective case-control study. Questionnaires were used to assess various aspects of patient QOL before and after orthognathic surgery in all studies. Only one prospective case-control study also assessed control subject QOL. The mean sample size was 57 (range, 15 to 152), and participants' ages ranged from 11 to 61 years. The studies were conducted in various geographic regions. Specifically, five studies were conducted in 
Europe, four studies were conducted in Asia, three studies were conducted in South America, and one study was conducted in Africa. The critical appraisal of the included studies, including an evaluation of study bias is shown in Table 2 .

[Insert table 1 near here]

[Insert table 2 near here]

The majority of the studies included herein recruited participants who underwent various types of orthognathic surgery. Three studies included only patients who underwent bimaxillary osteotomies, and one study included only patients who underwent bilateral sagittal ramus osteotomy for class III skeletal deformities. The following QOL assessment tools were used: the Oral Health Impact Profile14 (OHIP-14; see Supplementary Data S1), ${ }^{5}$ in 6 studies; the Orthognathic Quality of Life Questionnaire-22 (OQLQ-22; see Supplementary Data S2), ${ }^{6}$ in 5 studies; the Short Form Health Survey (SF-36; see Supplementary Data S3), ${ }^{7,8}$ in 4 studies; the Oral Health Impact Profile-49 (OHIP49: not shown), ${ }^{9}$ in 1 study; the World Health Organization Quality of Life, ${ }^{10}$ in 1 study; and the Derriford Appearance Scale 59 (DAS59: not shown), ${ }^{11}$ in 1 study. Four studies used their own investigator-created (and non-validated) questionnaires, and many studies used more than one assessment instrument. One study ${ }^{12}$ using the OHIP-14 added 3 additional questions regarding discomfort during chewing, satisfaction with facial aesthetics, and loss of sensation, respectively. No study was free of bias.

\section{Domain Outcomes}

\section{Physical Functioning and Limitations}

Twelve studies assessed whether patients experienced changes in physical functioning and limitations after orthognathic surgery. Some used one type of questionnaire, whereas others used more than one type of questionnaire to assess this domain. As shown in Table 3, most of the studies ${ }^{13-17}$ using the OHIP-14 and OQLQ-22 reported that patients experienced significant improvements in physical functioning and functional limitations after orthognathic surgery, whereas the four studies using the

This article is protected by copyright. All rights reserved 
SF-36 reported that patients did not experience significant improvements in physical functioning postsurgery. ${ }^{13,14,18,19}$ Other studies using different types of assessment instruments also reported that patients experienced improvements in physical functioning and limitations. For example, Silva et al. ${ }^{20}$ used the WHOQOL-Brief questionnaire and reported that $40 \%$ of participants had 'bite problems' preoperatively and that $86.7 \%$ of patients reported a high physical score postoperatively. Modig et al. ${ }^{21}$ used an investigator-created questionnaire, namely, the OHIP-49, and telephone interviews and reported that $18.6 \%$ of 32 participants initially sought treatment to improve their chewing ability, and $4.1 \%$ of participants sought treatment to improve their pronunciation ability. Postoperatively, $91 \%$ of patients reported improvements in their chewing ability, and 19\% reported improvements in their speech.

[Insert table 3 near here]

\section{Physical Pain}

Seven studies assessed whether patients experienced changes in physical pain after surgery. Six studies used the OHIP-14, and three used the SF-36. As shown in Table 4, most of the studies using the OHIP-14 13,14,16,17 reported that patients experienced significant improvements in physical pain postoperatively, whereas all the studies using the SF-36 questionnaire reported that patients experienced no changes in physical (bodily) pain after surgery. ${ }^{13,16,17}$

[Insert table 4 near here]

\section{Psychological Well-Being and Self-Esteem}

Eleven studies assessed whether patients experienced changes psychological well-being and selfesteem. Six studies used the OHIP-14, four studies used the SF-36, five studies used the OQLQ-22, and one study used another assessment instrument. As depicted in Table 5, all of the studies using the OHIP-14 postoperatively, ${ }^{12-15,16,17,23}$ some of the studies ${ }^{13,18}$ using the SF-36, and most of the studies ${ }^{14,15,22}$ using the OQLQ-22 (awareness domain) noted that patients experienced improvements in psychological well-being and self-esteem postoperatively. In the lone study using other assessment instruments to assess whether patients experienced changes in this domain, Silva and colleagues ${ }^{20}$

This article is protected by copyright. All rights reserved 
reported that participants experienced minimal changes in self-esteem; however, these authors also noted that most of their patients had exhibited high self-esteem before surgery. Moreover, two of the three subjects who exhibited fair self-esteem preoperatively exhibited good self-esteem postoperatively.

\section{[Insert table 5 near here]}

\section{Self-perception with regards to facial aesthetics}

Ten studies assessed whether patients experienced changes in self-perception with regards to facial aesthetics. Specifically, five studies used the OQLQ-22, and five studies used other assessment tools. All studies noted that patients experienced improvement in this domain after orthognathic surgery (Table 6).

[Insert table 6 near here]

\section{Social Functioning and Relationships}

Twelve studies assessed whether patients experienced improvements in social functioning and relationships. Six studies used the OHIP-14, four studies used the SF-36, five studies used the OQLQ22, and two studies used other assessment tools. As shown in Table 7, studies ${ }^{13,14,16}$ using OHIP-14 reported that patients generally experienced moderate improvement in this domain after orthognathic surgery, and studies ${ }^{13,14,15,22}$ using the OQLQ-22 reported that patients experienced moderate or large improvement in this domain post-surgery. Studies using the SF-36 reported that patients experienced variable improvements in social functioning and relationships, ${ }^{13,14,18,19}$ and the two studies ${ }^{20,21}$ using other assessment tools reported mixed results with respect to the changes that patients experienced in the indicated domain. Silva et al. ${ }^{19}$ reported that $64.3 \%$ of participants experienced no changes in their professional relationships, $21.4 \%$ of participants experienced slight changes in their professional relationships, and $14.3 \%$ of participants experienced significant changes in their professional relationships postoperatively. These authors also reported that $60 \%$ of participants reported no changes in their social relationships, whereas $20 \%$ of participants noted slight improvement in their 
social relationships, and $20 \%$ of participants reported significant improvement in their social relationships postoperatively. Modig et al. ${ }^{21}$ reported that $12 \%$ of participants tended to avoid public places and that $17 \%$ of participants had difficulty with respect to opposite-sex relationships preoperatively. However, these authors noted that $72 \%$ of participants felt more secure with respect to meeting people postoperatively.

[Insert table 7 near here]

\section{Discussion}

The aim of this systematic review was to assess changes in patient QOL in five domains following orthognathic surgery. We observed significant heterogeneity among the 13 included studies with respect to the populations evaluated and the orthognathic procedures, assessment tools, assessment schedules, and follow-up durations used therein. Thus, it was not appropriate to pool the data for meta-analysis.

\section{Quality of Life Outcomes}

Overall, the studies reported that patients experienced moderate or large changes in QOL after undergoing orthognathic surgery. Significant improvements were observed in all five QOL domains. Therefore, it is reasonable to conclude that orthognathic surgery has a substantial positive impact on QOL among patients who seek treatment for their conditions.

The greatest improvements in QOL were observed in the "psychological well-being and selfesteem' and 'self-perception with regards to facial aesthetics' domains. Most of the studies using the OHIP-14 noted that patients experienced more significant changes in psychological distress/discomfort and disability than in any other aspects of their lives. The effect sizes for changes in these two categories were considered large ( 0.84 and 0.83 ), whereas the effect sizes for changes in the other domains were considered moderate ( 0.65 to 0.77$)$ in the study by Göelzer et al. ${ }^{16}$ The effect sizes for changes in the two domains were also larger than those in all the other domains in the two other studies ${ }^{13,14}$ reporting effect sizes for changes in OHIP-14 psychological categories. In studies

This article is protected by copyright. All rights reserved 
using the OHIP-14 that did not calculate effect sizes, the mean differences for these two psychological categories were greater than those for all the other OHIP-14 domains.

Of the five domains, self-perception with regards to facial aesthetics demonstrated the greatest change in every study using the OQLQ-22. Choi et al. ${ }^{14}$ and Lee et al. ${ }^{13}$ reported effect sizes of 1.52 and 1.01, respectively, for postoperative changes in QOL in the aesthetic domain. Similarly, Murphy et al. ${ }^{15}$ and Soh and Narayan ${ }^{22}$ reported effect sizes for changes in QOL in the aesthetic domain that were greater than the corresponding effect sizes for changes in QOL in the other domains. In the study by Rustemeyer and Gregersen, ${ }^{12}$ an additional question regarding patient satisfaction with respect to aesthetic changes (known as AD-2) demonstrated a larger improvement after surgery than the other OHIP-14 items.

Our finding that psychological well-being and self-esteem and self-perception with regards to facial aesthetics were the domains influenced most positively by orthognathic surgery is consistent with the findings of two previous systematic reviews. ${ }^{25,26}$ Furthermore, our observation that patients experienced substantial benefits in both domains suggests that they may be interrelated. Thus, it may be useful for future studies to investigate the potential correlation between the two domains.

Our finding that surgery had a significant impact on aesthetic outcomes indicates that aesthetics is one of the most important issues to consider when planning orthognathic surgery. The finding is also consistent with the findings of previous studies, ${ }^{24,26-28}$ in which appearance improvement was one of the most popular reasons why patients sought orthognathic surgery. Interestingly, although oral functional improvement was the most common factor that motivated patients to undergo surgery in several studies ${ }^{21,29-31}$ the findings of the current review, which are based on patient responses to relevant questionnaire items, demonstrate that function does not appear to improve as much as aesthetics and psychological being. Despite the fact that post-surgery aesthetic changes are an important factor in patient decisions regarding surgery, many previous studies used questionnaires such as the SF-36 or OHIP-14, which do not include an aesthetic domain, to assess changes in QOL after orthognathic surgery. Future studies should use questionnaires with specific dentofacial aesthetic domains or incorporate additional assessment methods to review the changes in aesthetics experienced by patients who have undergone orthognathic surgery.

This article is protected by copyright. All rights reserved 


\section{Outcomes and Assessment Tools}

The current review showed that the SF-36, in contrast to most other evaluation instruments, often reported that patients experienced minimal or no changes in all the indicated domains. This finding may be attributable to the fact that almost every SF-36 question refers to general health- as opposed to dento-facial-related issues. For instance, the questions regarding changes in physical function pertain to activities such as running or walking. Additionally, the SF-36 questionnaire includes no questions regarding the aesthetic domain, whose importance is discussed above. Therefore, the SF-36 is a less appropriate tool for assessing QOL in patients with dento-facial abnormalities than other more condition-specific assessment tools.

The OHIP-14 was useful for assessing changes in the following four domains: physical functioning and limitations, physical pain, psychological well-being and self-esteem, and social functioning and relationships, and therefore focused on key outcomes that would be assessed following surgery that would be important to patients. The changes in QOL detected by the OHIP-14 were similar to those detected by the OQLQ-22 and other assessment instruments. Thus, although the OHIP-14 was designed to assess general oral health-related QOL, it is also capable of evaluating QOL before and after orthognathic surgery. However, as is the case with the SF-36, the OHIP-14 does not include an aesthetic domain section. Therefore, one should consider modifying the OHIP-14 or asking additional aesthetics-related questions when using the questionnaire for studies involving patients who have undergone orthognathic surgery. However, any questionnaire modifications or additional questions employed in such studies should be validated and standardised so that the outcome data obtained therein can be reliably pooled in future meta-analyses.

The OQLQ-22 also noted significant changes in the functional, psychological, and social domains after orthognathic surgery, changes that were generally greater than those noted by the OHIP-14 in the same domains, with the exception of the psychological domain. As noted above, of all the domains assessed by the indicated questionnaire, the aesthetic domain displayed the greatest changes. These results are similar to those obtained using the global transitional scale (GTS), which was used to confirm the results of the OQLQ-22 in the study by Murphy et al. ${ }^{15}$ wherein $46 \%$ of participants who completed the GTS reported large improvements in appearance surpassing those in other domains (including appearance, chewing, comfort, and speech). However, the OQLQ-22 lacks a 
domain for assessing pain, an important QOL determinant in patients undergoing orthognathic surgery. Assessing pain related to temporomandibular disorders (TMDs) is particularly important, as such disorders are very common in patients with dento-facial abnormalities. ${ }^{32-34}$ Some studies ${ }^{35,36}$ have demonstrated that TMDs worsened significantly after orthognathic surgery, whereas other studies $^{37,38}$ have reported that TMDs improved significantly. Using the OQLQ-22 and OHIP-14 together is an option for overcoming the deficiencies of each assessment tool, and such a strategy was used by some of the studies ${ }^{13,14}$ included in this review.

Regarding the other assessment tools used by studies included in this review, the nonvalidated (investigator-created) questionnaires, VAS, WHOQOL-Brief, and DAS59 demonstrated no significant changes in the psychological domains. Social functioning outcomes remained unchanged in the study by Silva et al. ${ }^{20}$ but reportedly improved in the study by Modig et al. ${ }^{21}$ However, the results of the latter study were not conclusive, as the preoperative and postoperative data reported therein did not pertain to equivalent outcomes. The preoperative data pertained to questions regarding avoidance of public places and relationships with the opposite sex, whereas the postoperative data pertained to questions regarding feelings of security when meeting people. In contrast, other assessment tools noted dramatic changes in aesthetic outcomes. Silvola et al. ${ }^{17}$ and Rustemeyer and Gregersen ${ }^{12}$ both reported changes in aesthetic-related scores that were greater than those in other domains. Similarly, Sadek and Salem ${ }^{24}$ noted significant improvements in all three domains of the DAS59 (a questionnaire that specialises in assessing subjective perceptions of aesthetics) following surgery. These results highlight the importance of evaluating changes in self-perceptions with respect to facial aesthetics when assessing orthognathic surgery outcomes.

\section{Limitations}

Only one study, namely, the study by Göezler et al. ${ }^{16}$ assessed the relationship between postoperative hypoesthesia and the above QOL domains. In that study, 72\% of participants reported loss of sensation; however, OHIP domain scores did not differ between patients with or without hypoesthesia. Further studies are required to explore this relationship, as neurosensory disturbances after orthognathic surgery are relatively common and may affect patient QOL. 39,40

This article is protected by copyright. All rights reserved 
Additionally, bias likely affected the results of the included studies. The objective of this review was to summarise the results of studies regarding orthognathic surgery; however, many studies ${ }^{12-14,18,22}$ recruited only participants who had specific type(s) of dento-facial deformities or required only a specific orthognathic procedure. Therefore, it may be inappropriate to extrapolate the results of these studies to the entire orthognathic surgery population. Preoperative assessments and pre-surgical orthodontic procedures, which were performed in some studies, ${ }_{13,15,16,18-22,24}$ may have been another source of bias, as the orthodontic treatments themselves may have affected the accuracy of the assessment tools utilised in the studies included in this review.

Furthermore, many studies did not calculate effect sizes for changes in specific QOL domains between the pre- and postoperative periods, which reduced the ability of the studies in question to quantify any changes in QOL.

\section{Conclusions}

This review demonstrated that orthognathic surgery generally yields significant improvements in QOL in the following five main domains: physical functioning and limitations, physical pain, psychological well-being and self-esteem, self-perception with regards to facial aesthetics, and social functioning and relationships. Psychological well-being and self-esteem and self-perception with regards to aesthetics were the two domains in which the greatest surgery-related benefits were observed. Thus, aesthetic domains should be assessed in any future studies examining outcomes after orthognathic surgery. The SF-36 is not suitable for evaluating QOL in patients undergoing orthognathic surgery. The OHIP-14 and OQLQ-22 are more useful assessments tools than the SF-36; however, they should be modified and/or used in combination to optimally assess changes in QOL in patients undergoing orthognathic surgery.

This article is protected by copyright. All rights reserved 


\section{Acknowledgments}

None

\section{Source of Funding}

No funding was provided for the writing or publication of this review.

\section{Conflict of Interest}

The authors confirm there are no conflicts of interest regarding the publication of this manuscript.

Ethical Approval - No ethical approval was required for this review.

This article is protected by copyright. All rights reserved 


\section{References}

1. Bockmann R, Meyns J, Dik E, Kessler P. The modifications osteotomy: a literature review. Plast Reconstr Surg Glob Open 2014;2:e271.

2. Gavric A et al. Craniodentofacial characteristics, dental esthetics-related quality of life, and self-esteem. American Journal of Orthodontics and Dentofacial Orthopedics , Volume 147 , Issue $6,711-718$

3. Moher D, Liberati A, Tetzlaff J, Altman DG. Preferred reporting items for systematic reviews and meta-analyses: the PRISMA statement. BMJ 2009;339:b2535.

4. CASP UK. n.d. CASP checklists. Middle Way (UK): critical appraisal skills programme [cited 2015 Aug 1]. Available from: http://www.casp-uk.net/\#!casp-tools-checklists/c18f8. http://www.casp-uk.net/

5. Slade GD. Derivation and validation of a short-form oral health impact profile. Community Dent Oral Epidemiol 1997;25:284-90.

6. Cunningham SJ, Garratt AM, Hunt NP. Development of a condition-specific quality of life measure for patients with dentofacial deformity: II. Validity and responsiveness testing. Community Dent Oral Epidemiol 2002;30:81-90.

7. Ware J, Snoww K, Kosinski M, Gandek B. SF36 health survey: manual and interpretation guide. Boston (MA): The Health Institute, New England Medical Center, 1993.

8. RAND Corporation. n.d. 36-item short form survey from the rand medical outcomes. Santa Monica, (CA): RAND Corporation [cited 2015 Aug 1]. Available from: http://www.rand.org/health/surveys_tools/mos/mos_core_36item.html

9. Slade GD, Spencer AJ. Development and evaluation of the oral health impact profile. Community Dent Health 1994;11:3-11.

10. WHOQOL. n.d. Measuring quality of life. Geneva (Switzerland): World Health Organization [cited 2015 Aug 1]. Available from: http://www.who.int/healthinfo/survey/whoqolqualityoflife/en/

11. Carr T, Harris D, James C. The derriford appearance scale (DAS-59): a new scale to measure individual responses to living with problems of appearance. Br J Health Psychol 2010;5:20115.

This article is protected by copyright. All rights reserved 
12. Rustemeyer J, Gregersen J. Quality of life in orthognathic surgery patients: post-surgical improvements in aesthetics and self-confidence. J Craniomaxillofac Surg 2012;40:400-4.

13. Lee S, McGrath C, Samman N. Impact of orthognathic surgery on quality of life. J Oral Maxillofac Surg 2008;66:1194-9.

14. Choi WS, Lee S, McGrath C, Samman N. Change in quality of life after combined orthodontic-surgical treatment of dentofacial deformities. Oral Surg Oral Med Oral Pathol Oral Radiol Endod 2010;109:46-51.

15. Murphy C, Kearns G, Sleeman D, Cronin M, Allen PF. The clinical relevance of orthognathic surgery on quality of life. Int J Oral Maxillofac Surg 2011;40:926-30.

16. Goelzer JG, Becker OE, Haas Junior OL, Scolari N, Santos Melo MF, Heitz C et al. Assessing change in quality of life using the oral health impact profile (OHIP) in patients with different dentofacial deformities undergoing orthognathic surgery: a before and after comparison. Int $\mathrm{J}$ Oral Maxillofac Surg 2014;43:1352-9.

17. Silvola AS, Varimo M, Tolvanen M, Rusanen J, Lahti S, Pirttiniemi P. Dental esthetics and quality of life in adults with severe malocclusion before and after treatment. Angle Orthod 2014;84:594-9.

18. Nicodemo D, Pereira MD, Ferreira LM. Effect of orthognathic surgery for class III correction on quality of life as measured by SF-36. Int J Oral Maxillofac Surg 2008;37:131-4.

19. Khadka A, Liu Y, Li J, Zhu S, Luo E, Feng G et al. Changes in quality of life after orthognathic surgery: a comparison based on the involvement of the occlusion. Oral Surg Oral Med Oral Pathol Oral Radiol Endod 2011;112:719-5.

20. Silva AC, Carvalho RA, de Santana TS, Rocha NS, Gomes AC, de Oliveira SE. Evaluation of life quality of patients submitted to orthognathic surgery. Dental Press J Orthod 2013;18:107114.

21. Modig M, Andersson L, Wardh I. Patients' perception of improvement after orthognathic surgery: pilot study. Br J Oral Maxillofac Surg 2006;44:24-7.

22. Soh CL, Narayanan V. The impact of surgical correction on the quality of life in patients with dentofacial deformity - A prospective study. J Oral Maxillofac Surg, Med, Pathol 2015;27:323-7.

This article is protected by copyright. All rights reserved 
23. Rustemeyer J, Martin A, Gregersen J. Changes in quality of life and their relation to cephalometric changes in orthognathic surgery patients. Angle Orthod 2012;82:235-41.

24. Sadek H, Salem G. Psychological aspects of orthognathic surgery and its effect on quality of life in Egyptian patients. East Mediterr Health J 2007;13:150-9.

25. Soh CL, Narayanan V. Quality of life assessment in patients with dentofacial deformity undergoing orthognathic surgery--a systematic review. Int J Oral Maxillofac Surg 2013;42:974-80.

26. Hunt OT, Johnston CD, Hepper PG, Burden DJ. The psychosocial impact of orthognathic surgery: a systematic review. Am J Orthod Dentofacial Orthop 2001;120:490-7.

27. Oland J, Jensen J, Elklit A, Melsen B. Motives for surgical-orthodontic treatment and effect of treatment on psychosocial well-being and satisfaction: a prospective study of 118 patients. $\mathrm{J}$ Oral Maxillofac Surg 2011;69:104-13.

28. Olson RE, Laskin DM. Expectations of patients from orthognathic surgery. J Oral Surg 1980;38:283-285.

29. Oland J, Jensen J, Papadopoulos MA, Melsen B. Does skeletal facial profile influence preoperative motives and postoperative satisfaction? A prospective study of 66 surgicalorthodontic patients. J Oral Maxillofac Surg 2011;69:2025-32.

30. Proothi M, Drew SJ, Sachs SA. Motivating factors for patients undergoing orthognathic surgery evaluation. J Oral Maxillofac Surg 2010;68:1555-9.

31. Forssell H, Finne K, Forssell K, Panula K, Blinnikka LM. Expectations and perceptions regarding treatment: a prospective study of patients undergoing orthognathic surgery. Int $\mathbf{J}$ Adult Orthodon Orthognath Surg 1998;13:107-13.

32. Abrahamsson C. Masticatory function and temporomandibular disorders in patients with dentofacial deformities. Swed Dent J Suppl 2013;9-85.

33. Cascone P, Di Paolo C, Leonardi R, Pedulla E. Temporomandibular disorders and orthognathic surgery. J Craniofac Surg 2008;19:687-92.

34. Dujoncquoy JP, Ferri J, Raoul G, Kleinheinz J. Temporomandibular joint dysfunction and orthognathic surgery: a retrospective study. Head Face Med 2010;6:27.

This article is protected by copyright. All rights reserved 
35. Onizawa K, Schmelzeisen R, Vogt S. Alteration of temporomandibular joint symptoms after orthognathic surgery: comparison with healthy volunteers. J Oral Maxillofac Surg 1995;53:117-21; discussion 122-13.

36. Wolford LM, Reiche-Fischel O, Mehra P. Changes in temporomandibular joint dysfunction after orthognathic surgery. J Oral Maxillofac Surg 2003;61:655-60; discussion 661.

37. Karabouta I, Martis C. The TMJ dysfunction syndrome before and after sagittal split osteotomy of the rami. J Maxillofac Surg 1985;13:185-8.

38. Magnusson T, Ahlborg G, Svartz K. Function of the masticatory system in 20 patients with mandibular hypo- or hyperplasia after correction by a sagittal split osteotomy. Int J Oral Maxillofac Surg 1990;19:289-93.

39. Degala S, Shetty SK, Bhanumathi M. Evaluation of neurosensory disturbance following orthognathic surgery: a prospective study. J Maxillofac Oral Surg 2015;14:24-31.

40. Lee EG, Ryan FS, Shute J, Cunningham SJ. The impact of altered sensation affecting the lower lip after orthognathic treatment. J Oral Maxillofac Surg 2011;69:e431-45. 


\section{Figure Legends}

Figure 1. Flow diagram of the study selection process

Table 1. Characteristics of the Included Studies

Table 2. Critical Appraisal of the Included Studies

Table 3. Physical Function and Limitation Before and After Orthognathic Surgery

Table 4. Physical Pain Before and After Orthognathic Surgery

Table 5. Psychological Well-being and Self-esteem Before and After Orthognathic Surgery

Table 6. Self-perception with Regards to Facial Aesthetics Before and After Orthognathic Surgery

Table 7. Social Functioning and Relationships Before and After Orthognathic Surgery

This article is protected by copyright. All rights reserved 
Table 1. Characteristics of the Included Studies

\begin{tabular}{|c|c|c|c|c|c|c|c|c|c|}
\hline $\begin{array}{l}\text { Study } \\
\text { authors }\end{array}$ & $\begin{array}{l}\text { Study } \\
\text { design }\end{array}$ & Participants & $\begin{array}{l}\text { Sample } \\
\text { size }\end{array}$ & $\begin{array}{l}\text { Age } \\
(y)\end{array}$ & $\begin{array}{l}\text { Exclusion } \\
\text { criteria }\end{array}$ & Instruments & $\begin{array}{l}\text { Assessment } \\
\text { schedule }\end{array}$ & Outcomes & Data analysis \\
\hline $\begin{array}{l}\text { Göelzer et } \\
\text { al. }{ }^{15}\end{array}$ & $\begin{array}{l}\text { Prospective } \\
\text { cohort }\end{array}$ & $\begin{array}{l}\text { Patients with } \\
\text { dento-facial } \\
\text { deformities } \\
\text { (including } \\
\text { Angle class I, } \\
\text { II, and III } \\
\text { deformities) } \\
\text { who presented } \\
\text { for treatment } \\
\text { from } 2010 \text { to } \\
2013\end{array}$ & 74 & $\begin{array}{l}15-53 \\
(28.0 \pm \\
9.0)\end{array}$ & $\begin{array}{l}\text { Patients with } \\
\text { cleft lip and } \\
\text { palate, } \\
\text { syndromes, } \\
\text { facial } \\
\text { deformities } \\
\text { caused by } \\
\text { trauma or } \\
\text { congenital } \\
\text { malformations, } \\
\text { pre-existing } \\
\text { systemic } \\
\text { disease, } \\
\text { pregnancy, } \\
<15 \text { years old }\end{array}$ & $\begin{array}{l}\text { OHIP-14; } \\
\text { questions on } \\
\text { degree of lip } \\
\text { hypoesthesia } \\
\text { (ratings } \\
\text { ranged from } \\
\text { 'none' [score, } \\
\text { 1] to } \\
\text { 'extreme' } \\
\text { [score, 5]) }\end{array}$ & $\begin{array}{l}\text { Preop: OHIP- } \\
14 \text { before } \\
\text { surgery }\left(\mathrm{T}_{0}\right) \\
\text { Postop: OHIP- } \\
14 \text { and } \\
\text { hypoesthesia } \\
\text { questions at 4-6 } \\
\text { months after } \\
\text { surgery }\left(\mathrm{T}_{1}\right)\end{array}$ & $\begin{array}{l}\text { Pre- and } \\
\text { postop OHIP- } \\
14 \text { scores }\end{array}$ & $\begin{array}{l}\text { Kolmogorov-Smirnov } \\
\text { test to assess data } \\
\text { normality; Fisher's } \\
\text { exact test to assess the } \\
\text { associations among } \\
\text { gender, age, type of } \\
\text { surgery, and type of } \\
\text { deformity; Wilcoxon } \\
\text { matched-pairs test to } \\
\text { assess the changes in } \\
\text { OHIP-14 scores } \\
\text { between } \mathrm{T}_{0} \text { and } \mathrm{T}_{1} \text {; } \\
\text { calculation of test power } \\
\text { and effect sizes; } \\
\text { Spearman's correlation } \\
\text { coefficient to assess the } \\
\text { correlations between the } \\
\text { above changes in OHIP- } \\
14 \text { scores and OHIP-14 } \\
\text { domains; level of } \\
\text { significance set at } 5 \%\end{array}$ \\
\hline Choi et al. ${ }^{13}$ & Prospective & All ASA class I & 32 & $23.94 \pm$ & Patients with & SF-36, OHIP- & Preop: all & Pre- and & Overall scores and \\
\hline
\end{tabular}

This article is protected by copyright. All rights reserved 


\begin{tabular}{|c|c|c|c|c|c|c|c|c|}
\hline cohort & $\begin{array}{l}\text { and II patients } \\
\text { scheduled to } \\
\text { undergo } \\
\text { bimaxillary } \\
\text { surgery and } \\
\text { receive } \\
\text { orthodontic } \\
\text { therapy }\end{array}$ & & 6.65 & $\begin{array}{l}\text { physical } \\
\text { disabilities; } \\
\text { pain or } \\
\text { discomfort in } \\
\text { any part of } \\
\text { the body; } \\
\text { syndromes or } \\
\text { congenital } \\
\text { deformities, } \\
\text { such as cleft } \\
\text { lip and palate; } \\
\text { and any } \\
\text { previous jaw } \\
\text { surgery }\end{array}$ & 14, OQLQ-22 & $\begin{array}{l}\text { questionnaires } \\
\text { at recruitment } \\
\left(\mathrm{T}_{0}\right) \\
\text { Postop: all } \\
\text { questionnaires } \\
\text { at } 6 \text { weeks } \\
\text { post-surgery } \\
\left(\mathrm{T}_{1}\right), 6 \text { months } \\
\text { post-surgery } \\
\left(\mathrm{T}_{2}\right) \text {, and after } \\
\text { orthodontic } \\
\text { treatment ( } \mathrm{T}_{3} \text {; at } \\
\text { least } 12 \text { months } \\
\text { after surgery } \\
\text { and } 6 \text { months } \\
\text { after } \\
\text { orthodontic } \\
\text { treatment) }\end{array}$ & $\begin{array}{l}\text { postop SF-36, } \\
\text { OHIP-14, and } \\
\text { OQLQ-22 } \\
\text { scores }\end{array}$ & $\begin{array}{l}\text { separate domain scores } \\
\text { were obtained; } \\
\text { Friedman 2-way } \\
\text { ANOVA to assess QOL } \\
\text { scores; Wilcoxon } \\
\text { signed-rank test to } \\
\text { assess the differences in } \\
\text { QOL scores between } \mathrm{T}_{0} \\
\text { and } \mathrm{T}_{1}, \mathrm{~T}_{0} \text { and } \mathrm{T}_{2} \text {, and } \\
\mathrm{T}_{0} \text { and } \mathrm{T}_{3} \text { calculation of } \\
\text { effect sizes }\end{array}$ \\
\hline $\begin{array}{l}\text { Prospective } \\
\text { case- } \\
\text { control }\end{array}$ & $\begin{array}{l}\text { Group A: } \\
\text { participants who } \\
\text { underwent pre- } \\
\text { op orthodontic } \\
\text { treatment and } \\
\text { required } \\
\text { orthognathic } \\
\text { surgery }\end{array}$ & $\begin{array}{l}152 \\
\text { (Group } \\
\text { A: } 110 \\
\text { Group } \\
\text { B: 42) }\end{array}$ & $\begin{array}{l}\text { Group } \\
\text { A: } 18-34 \\
(22.86) \\
\text { Group } \\
\text { B: } 20-37 \\
(27.21)\end{array}$ & $\begin{array}{l}\text { Both groups: } \\
\text { Patients with } \\
\text { physical } \\
\text { disabilities, } \\
\text { acquired or } \\
\text { congenital } \\
\text { deformities, } \\
\text { or any }\end{array}$ & $\begin{array}{l}\text { SF-36, } \\
\text { OQLQ-22 }\end{array}$ & $\begin{array}{l}\text { Preop: all } \\
\text { questionnaires } \\
\text { at } 30 \text { days } \\
\text { before surgery } \\
\text { Postop: all } \\
\text { questionnaires } \\
\text { at 6-8 months } \\
\text { post-surgery }\end{array}$ & $\begin{array}{l}\text { Pre- and } \\
\text { postop SF-36 } \\
\text { and OQLQ- } \\
22 \text { scores }\end{array}$ & $\begin{array}{l}\text { Calculation of mean, SD, } \\
\text { median, and 25th- and } \\
\text { 75th-percentile scores; } \\
\text { Wilcoxon signed-rank } \\
\text { test to assess the } \\
\text { differences in QOL } \\
\text { scores between the two } \\
\text { times; Mann-Whitney U }\end{array}$ \\
\hline
\end{tabular}

This article is protected by copyright. All rights reserved 


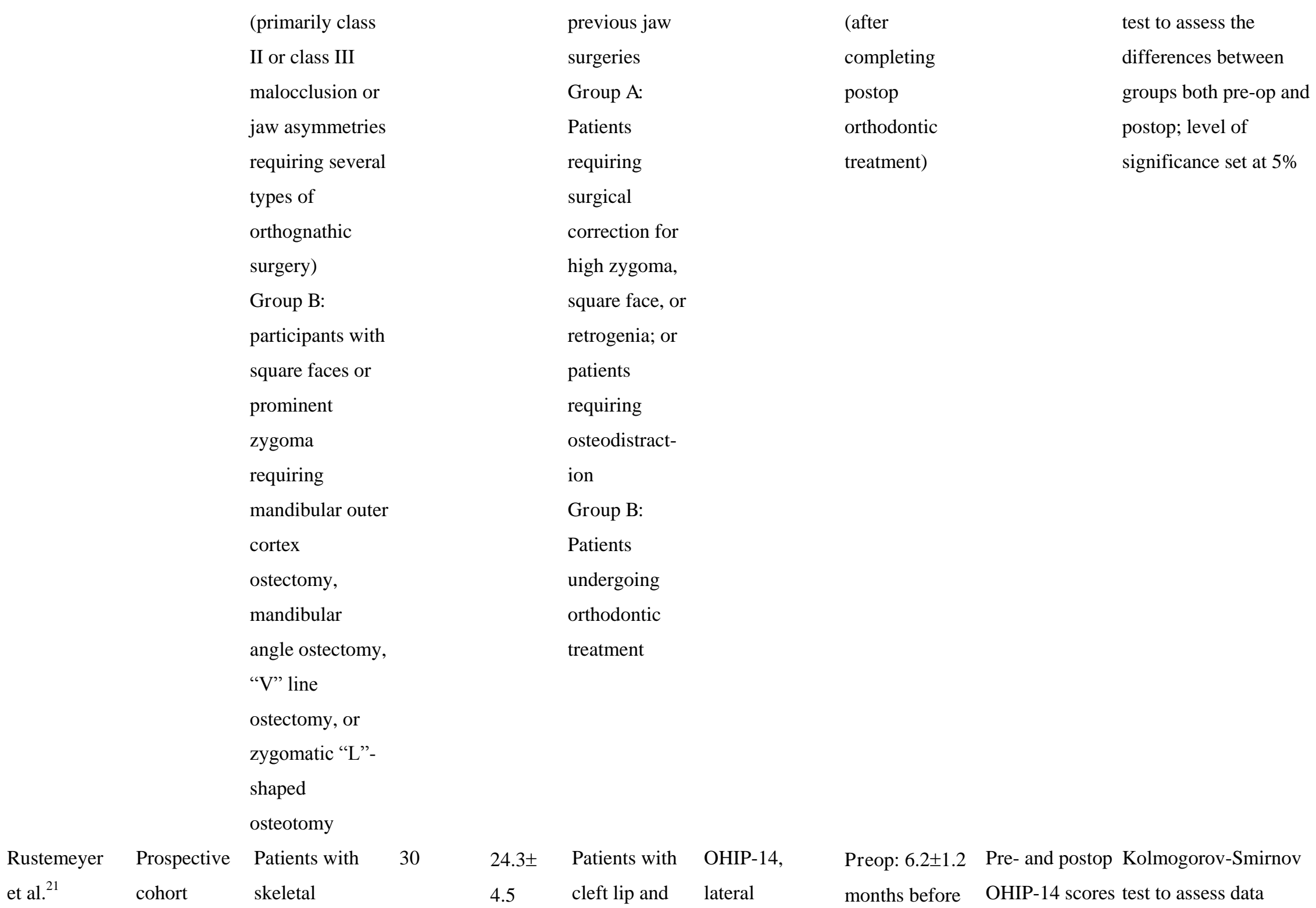

This article is protected by copyright. All rights reserved 


malformations
displaying
mandibular
prognathia
with class III
malocclusion

Silvola et

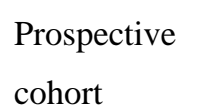

al. $^{16}$

cohort palate,

$\begin{array}{lll}\text { Patients } & 52 & 18-61 \\ \text { requiring either } & \text { (orthog- } & (21.0 \pm \\ \text { orthodontic or } & \text { nathic } & 4.1) \\ \text { surgical- } & \text { surgery } & \\ \text { orthodontic } & \text { group: } & \\ \text { treatment who } & 38, & \end{array}$

craniofacial

syndromes, or

post-traumatic

deformities;

patients

scheduled to

undergo

orthognathic

surgery

without

orthodontic

treatments or

additional

procedures,

such as

genioplasty or

distractor

device

placement

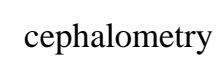

orthodontic

appliance

removal

NR

OHIP-14

(Finnish

version);

VAS;

Aesthetic

Component and

cephalometric

hard and soft

tissue

landmarks and $0.1 \%$; Pearson correlation

angles

analysis to assess the

correlation between the changes in OHIP-14 item scores and those in soft and hard tissues

$\begin{array}{lll}\text { Preop: OHIP- } & \text { Pre- and } & \text { Calculation of mean } \\ \text { 14, VAS, and } & \text { postop OHIP- } & \text { values and changes in } \\ \text { AC scores } & \text { 14, VAS, and } & \text { instrument scores; } \\ \text { before starting } & \text { AC scores } & \text { paired t test to assess the } \\ \text { treatment. } & & \text { differences before and } \\ \text { Postop: OHIP- } & & \text { after treatment; study }\end{array}$

This article is protected by copyright. All rights reserved 


\begin{tabular}{|c|c|}
\hline \multirow{2}{*}{$\begin{array}{l}\text { had severe } \\
\text { skeletal }\end{array}$} & orthodon- \\
\hline & tic group: \\
\hline malocclusion & 14) \\
\hline (diagnosed by & \\
\hline cephalometry) & \\
\hline and functional & \\
\hline disorders, such & \\
\hline as pain, & \\
\hline traumatic & \\
\hline occlusion, or & \\
\hline difficulty & \\
\hline masticating. & \\
\hline
\end{tabular}

$\begin{array}{ll}\text { (AC) of the } & 14 \text { and VAS } \\ \text { Index of } & \text { scores at } \\ \text { Orthodontic } & 3.1 \pm 1.22 \mathrm{y} \\ \text { Treatment } & \text { after treatment } \\ \text { Need score } & \text { and AC scores } \\ \text { (assessed by } & \text { at 3.0 } \pm 1.07 \mathrm{y} \\ \text { laypersons, } & \text { after treatment } \\ \text { dental } & \\ \text { students, and } & \\ \text { orthodontists } & \\ \text { using } & \\ \text { standardized } & \\ \text { dental } \\ \text { photographs) }\end{array}$

Nicodemo et Prospective Patients with cohort

Angle's class

III

malocclusion

(negative

overjet $\geq 4$

$\mathrm{mm})$ and

indications for

surgical

treatment who
Preop: 30 days Preop and

before surgery

Postop: 6

months after

surgery

scores group was divided into

subgroups according to

aesthetic satisfaction

quartiles to determine

the relationship between

aesthetic satisfaction

and OHIP-14 scores

using univariate general

linear modelling;

Pearson correlation

analysis to evaluate the

correlations between

changes in OHIP-14

scores and patient

aesthetic satisfaction

and $\mathrm{AC}$ scores

Descriptive statistics and

postop SF-36 inferential analysis used

to characterize and

compare variables;

repeated measures

ANOVA to compare

types of surgery, gender,

and time periods (pre-

and postop); multiple

comparisons using

This article is protected by copyright. All rights reserved 
had undergone

orthodontic

preparation for

$1-1.5$ y

$\begin{array}{lll}\text { Silva et al. }^{19} & \begin{array}{l}\text { Prospective } \\ \text { cohort }\end{array} & \begin{array}{l}\text { Patients with } \\ \text { dento-facial } \\ \text { deformities }\end{array} \\ & \text { who } \\ & \text { underwent } \\ & \text { corrective } \\ & \text { orthognathic } \\ & \text { surgery }\end{array}$

Lee et al. ${ }^{12}$

\begin{abstract}
cohort ASA class I or II
\end{abstract}

Bonferroni's test to

identify the specific items responsible for the

differences in the

ANOVA results; level of significance set at $5 \%$;

Pearson correlation

coefficients to examine

the correlation between

antero-posterior

discrepancies and QOL

\begin{tabular}{|c|c|}
\hline $17-35$ & Patients with \\
\hline$(25 \pm 5.7)$ & cleft lip or \\
\hline & palate or \\
\hline & other \\
\hline & uncontrolled \\
\hline & pathology \\
\hline & \\
\hline & \\
\hline & \\
\hline & \\
\hline $23.25 \pm$ & Patients with \\
\hline 6.60 & physical \\
\hline & disability, \\
\hline
\end{tabular}

Preop: Preop

questionnaire

on day of

hospitalization

created

questionnaire

postop self-

administered,

investigator-

created

questionnaire;

WHOQOL-

BREF

SF-36, OHIP- Preop: all

14, OQLQ-22

questionnaires

completed at

\section{BREF}

Collection of absolute

Participants'

preop and

postop

questionnaire

responses,

postop

WHOQOL-

BREF score

and percentile

distributions;

McNemar's test;

Fisher's exact test;

Student's $\mathrm{t}$ test with

equal and unequal

variables; Levene's F

test to verify the

hypothesis

Preop and Obtaining overall and

postop SF-36, domain scores;

OHIP-14, Wilcoxon signed-rank

This article is protected by copyright. All rights reserved 


malocclusion
who
completed pre-
surgical
orthodontic
treatment and
were about to
undergo
bimaxillary
orthognathic
surgery

Rustemeyer

and

Prospective Patients with

cohort

Gregersen ${ }^{11}$

skeletal class

II or III pain or

discomfort in

any body

part; patients

with

syndromes or

congenital

deformities,

such as cleft

lip and palate;

or patients

with any

previous jaw

surgery

50

malocclusion
18-52 Patients with

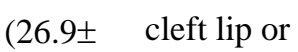

9.9)

palate or

craniofacial

syndromes;

patients

scheduled to

undergo

orthognathic

surgery

without

orthodontic

\section{recruitment}

$\left(\mathrm{T}_{0}\right)$

Post-op: all

questionnaires

completed at 6

weeks $\left(\mathrm{T}_{1}\right)$ and

6 months post-

surgery $\left(\mathrm{T}_{2}\right)$
OQLQ-22

scores

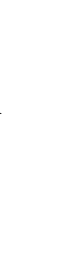




\begin{tabular}{|c|c|c|c|c|c|c|c|c|c|}
\hline & & & & & $\begin{array}{l}\text { treatments or } \\
\text { additional } \\
\text { procedures, } \\
\text { such as } \\
\text { genioplasty or } \\
\text { distractor } \\
\text { device } \\
\text { placement }\end{array}$ & & & & \\
\hline $\begin{array}{l}\text { Murphy et } \\
\text { al. }{ }^{14}\end{array}$ & $\begin{array}{l}\text { Prospective } \\
\text { cohort }\end{array}$ & $\begin{array}{l}\text { Patients with } \\
\text { congenital } \\
\text { deformities of } \\
\text { the maxilla } \\
\text { and/or } \\
\text { mandible or } \\
\text { both (without } \\
\text { symptoms } \\
\text { suggestive of a } \\
\text { syndrome) }\end{array}$ & 52 & $\begin{array}{l}18-38 \\
(21.6)\end{array}$ & $\mathrm{NR}$ & $\begin{array}{l}\text { OQLQ-22, } \\
\text { VAS, GTS }\end{array}$ & $\begin{array}{l}\text { Preop: } \\
\text { OQLQ-22 and } \\
\text { VAS during } \\
\text { the orthodontic } \\
\text { treatment } \\
\text { phase } \\
\text { Postop: } \\
\text { OQLQ-22, } \\
\text { VAS, and GTS } \\
\text { at } 6 \text { months } \\
\text { after surgery }\end{array}$ & $\begin{array}{l}\text { Preop and } \\
\text { postop } \\
\text { OQLQ-22, } \\
\text { VAS, and } \\
\text { GTS scores }\end{array}$ & $\begin{array}{l}\text { Determination of } \\
\text { descriptive statistics; } \\
\text { paired t tests to assess } \\
\text { the differences between } \\
\text { pre- and post-treatment } \\
\text { scores; significance } \\
\text { level set at 5\%; } \\
\text { calculation of effect } \\
\text { sizes for each domain }\end{array}$ \\
\hline $\begin{array}{l}\text { Soh and } \\
\text { Narayanan }^{22}\end{array}$ & $\begin{array}{l}\text { Prospective } \\
\text { cohort }\end{array}$ & $\begin{array}{l}\text { Patients with } \\
\text { dentofacial } \\
\text { deformities } \\
\text { and indications } \\
\text { for } \\
\text { orthognathic } \\
\text { surgery }\end{array}$ & 66 & $\begin{array}{l}18-30 \\
(23.4)\end{array}$ & $\begin{array}{l}\text { Patients with } \\
\text { congenital } \\
\text { craniofacial } \\
\text { deformities, } \\
\text { cleft lip and } \\
\text { palate, a } \\
\text { history of }\end{array}$ & $\begin{array}{l}\text { OQLQ-22 } \\
\text { with } 3 \\
\text { additional } \\
\text { postop } \\
\text { questions }\end{array}$ & $\begin{array}{l}\text { Preop: OQLQ- } \\
22 \text { during pre- } \\
\text { surgical } \\
\text { orthodontic } \\
\text { phase } \\
\text { Postop: } \\
\text { OQLQ-22 with }\end{array}$ & $\begin{array}{l}\text { Pre-op and } \\
\text { postop } \\
\text { OQLQ-22 } \\
\text { and } \\
\text { postoperative } \\
\text { questions } \\
\text { scores }\end{array}$ & $\begin{array}{l}\text { Paired } t \text { tests to assess } \\
\text { the differences between } \\
\text { pre- and post-treatment } \\
\text { scores; 1-way ANOVA } \\
\text { to assess the differences } \\
\text { in pre-op and postop } \\
\text { scores between }\end{array}$ \\
\hline
\end{tabular}

This article is protected by copyright. All rights reserved 


\begin{tabular}{|c|c|c|c|c|c|c|c|c|}
\hline & & & & $\begin{array}{l}\text { previous } \\
\text { orthognathic } \\
\text { surgery, and } \\
\text { an inability to } \\
\text { complete the } \\
\text { questionnaire }\end{array}$ & & $\begin{array}{l}3 \text { additional } \\
\text { questions at } \\
\text { least } 6 \text { months } \\
\text { after surgery }\end{array}$ & & $\begin{array}{l}\text { different types of dento- } \\
\text { facial deformities; } \\
\text { significance level set at } \\
5 \% \text {; calculation of } \\
\text { effect sizes for each } \\
\text { domain }\end{array}$ \\
\hline $\begin{array}{l}\text { Prospective } \\
\text { cohort }\end{array}$ & $\begin{array}{l}\text { Consecutive } \\
\text { healthy } \\
\text { patients who } \\
\text { underwent } \\
\text { combined } \\
\text { surgical- } \\
\text { orthodontic } \\
\text { treatment } \\
\text { from1999- } \\
2001 \text { and had } \\
\text { completed a } \\
\text { preop } \\
\text { questionnaire } \\
\text { (Questionnaire } \\
\text { 1) }\end{array}$ & 32 & $\begin{array}{l}20-59 \\
(32)\end{array}$ & NR & $\begin{array}{l}\text { Questionnaire 1 } \\
\text { (assessment of } \\
\text { previous } \\
\text { experience with } \\
\text { and knowledge } \\
\text { of malocclusion } \\
\text { and treatment } \\
\text { options, } \\
\text { medical and } \\
\text { psychological } \\
\text { function and } \\
\text { appearance); } \\
\text { Questionnaire 2 } \\
\text { (assessment of } \\
\text { treatment } \\
\text { impact; VAS } \\
\text { used for some } \\
\text { outcomes); } \\
\text { OHIP-49; } \\
\text { telephone }\end{array}$ & $\begin{array}{l}\text { Preop: } \\
\text { Questionnaire } 1 \\
\text { Postop: } \\
\text { Questionnaire 2, } \\
\text { OHIP-49, and } \\
\text { telephone } \\
\text { interview }\end{array}$ & $\begin{array}{l}\text { Participants' } \\
\text { responses to } \\
\text { questionnaire } \\
\mathrm{s} \text { and } \\
\text { telephone } \\
\text { interview; } \\
\text { postop OHIP- } \\
49 \text { score }\end{array}$ & NR \\
\hline
\end{tabular}

This article is protected by copyright. All rights reserved 


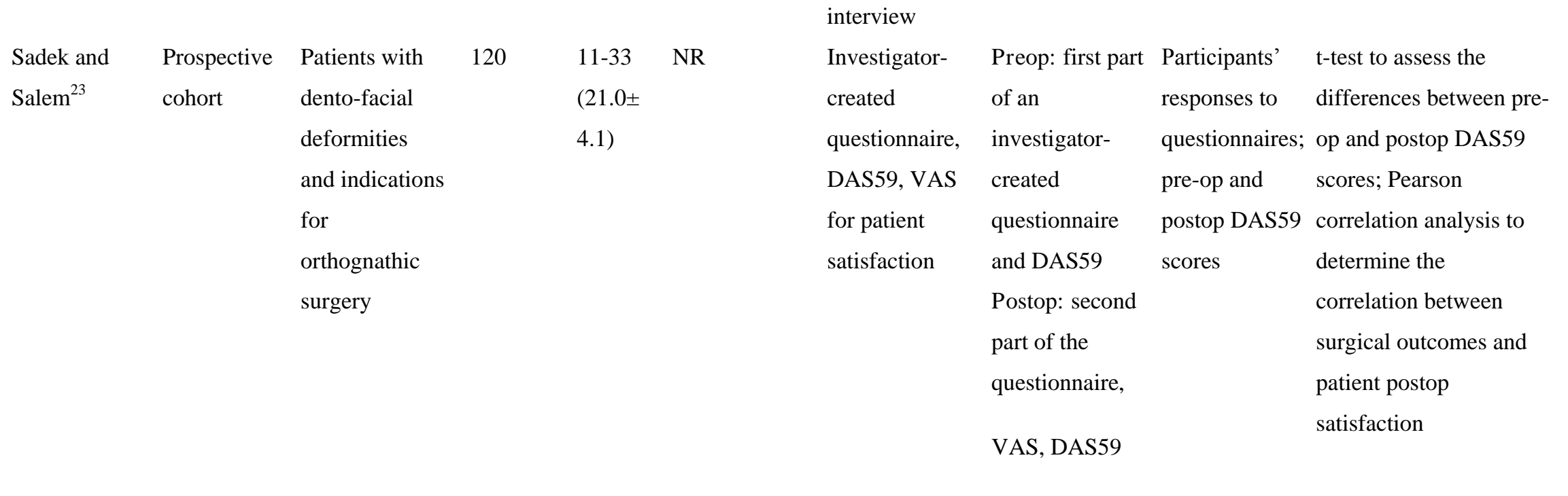

Age data are presented as means, means \pm standard deviations, and/or ranges.

Abbreviations: ANOVA, analysis of variance; ASA, American Society of Anesthesiologists; DAS59, Derriford Appearance Scale 59; GTS, global transition scale; NR, not reported; OHIP-14, Oral Health Impact Profile-14; OHIP-49, Oral Health Impact Profile-49; OQLQ-22, Orthognathic Quality of Life Questionnaire-22; preop, preoperative; postop, postoperative; QOL, quality of life; SF-36, Short Form Health Survey; VAS, visual analogue scale; WHOQOL-BREF, World Health Organization Quality of Life-BREF

This article is protected by copyright. All rights reserved 
Table 2. Critical Appraisal of the Included Studies

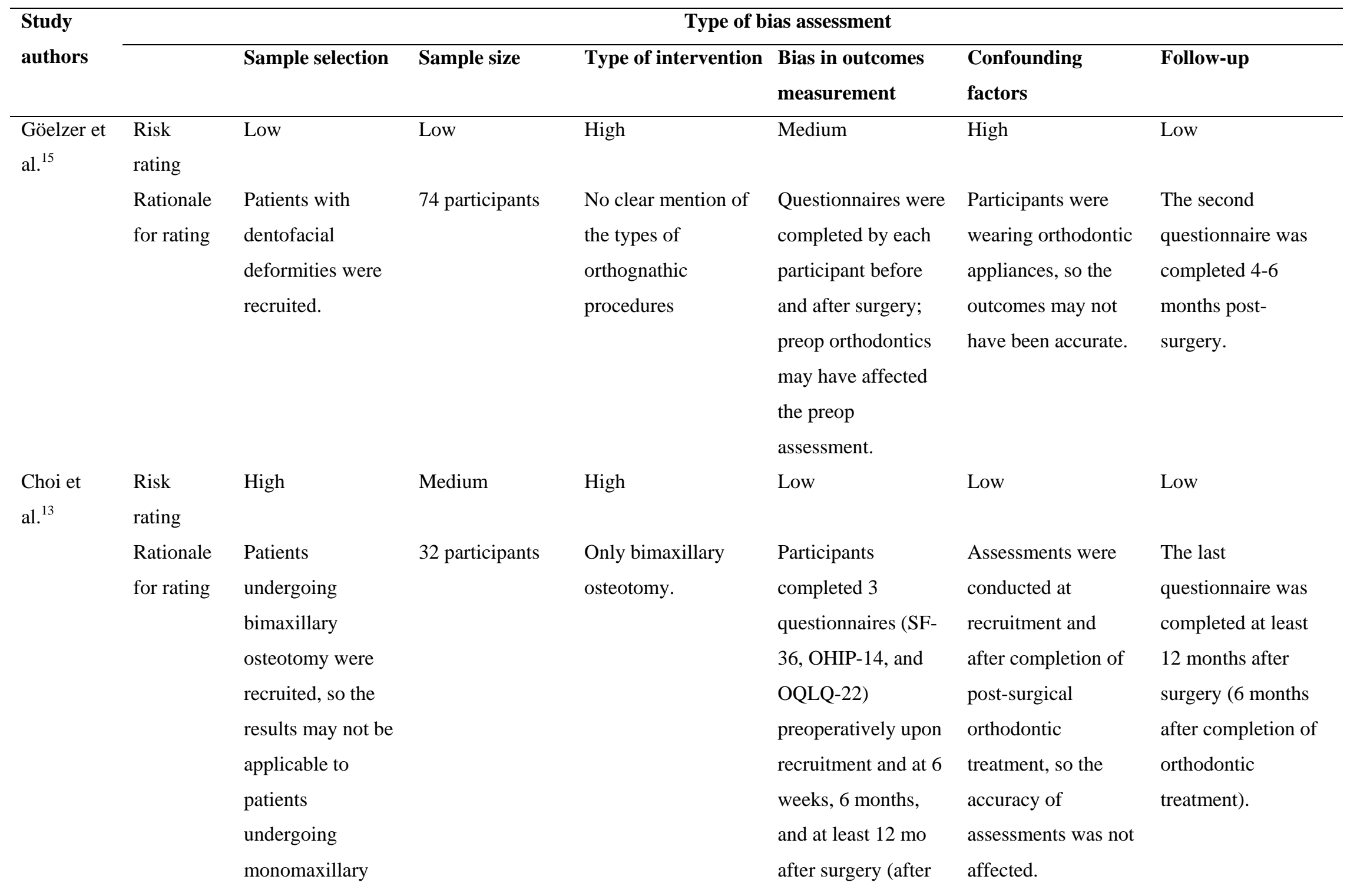

This article is protected by copyright. All rights reserved 
surgery.

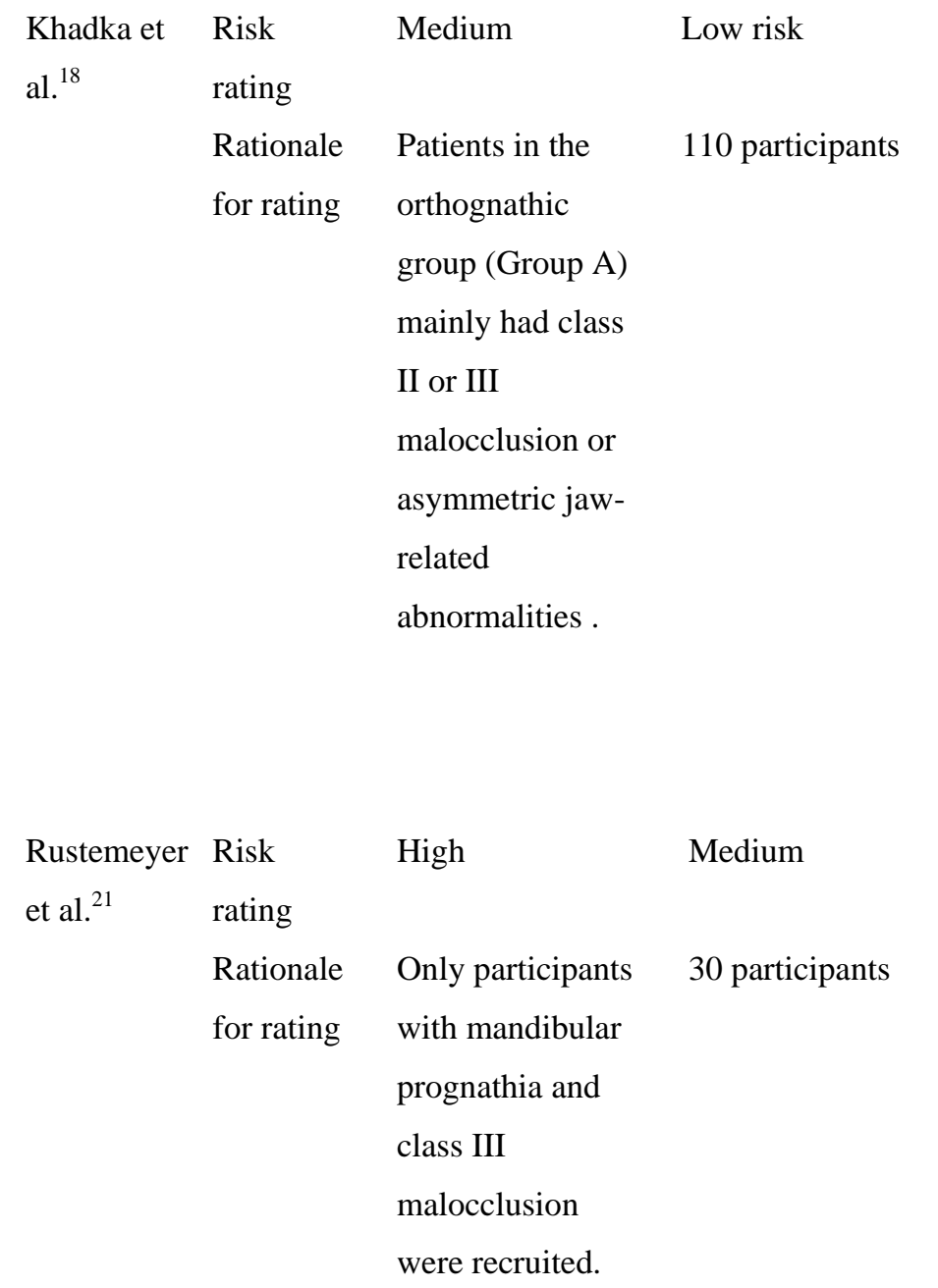

postop orthodontic

treatment was

complete).

Low risk

Medium risk

High risk

Low risk

Sagittal split Participants were

osteotomy, intraoral

assessed 30 days

preoperatively (the

vertical ramus

accuracy of these

measurements may

osteotomy, and

anterior sub-apical

segmental

osteotomy.

High

Only bilateral
sagittal split ramus
osteotomy.

Each patient

completed 1

questionnaire before

the orthodontic

appliances were

applied (6.2 \pm 1.2

months before

surgery) and another
Participants were

assessed

preoperatively while

undergoing

orthodontic

treatment.
The last

questionnaires were

completed 6-8

months after surgery.
Low

$\begin{array}{ll}\begin{array}{l}\text { Assessments were } \\ \text { performed before }\end{array} & \begin{array}{l}\text { The last } \\ \text { questionnaire was } \\ \text { the preop }\end{array} \\ \begin{array}{l}\text { orthodontics were } \\ \text { months after surgery }\end{array} \\ \begin{array}{l}\text { applied and after the } \\ \text { postop orthodontic }\end{array} & \text { appliance removal). } \\ \text { treatments were } & \\ \text { finished. }\end{array}$

This article is protected by copyright. All rights reserved 


\begin{tabular}{|c|c|c|c|c|c|c|c|}
\hline & & & & & $\begin{array}{l}\text { after the appliances } \\
\text { were removed } \\
\text { ( } 8.3 \pm 1.2 \text { months } \\
\text { after surgery). }\end{array}$ & & \\
\hline \multirow[t]{2}{*}{$\begin{array}{l}\text { Silvola et } \\
\text { al. }^{16}\end{array}$} & $\begin{array}{l}\text { Risk } \\
\text { rating }\end{array}$ & High & Medium & Low & Medium & Low & Low \\
\hline & $\begin{array}{l}\text { Rationale } \\
\text { for rating }\end{array}$ & $\begin{array}{l}\text { Patients requiring } \\
\text { surgical- } \\
\text { orthodontic (or } \\
\text { orthodontic } \\
\text { treatment alone) } \\
\text { treatment for } \\
\text { severe skeletal } \\
\text { malocclusion } \\
\text { were recruited. } \\
\text { Specific types of } \\
\text { malocclusion } \\
\text { were not } \\
\text { mentioned. }\end{array}$ & $\begin{array}{l}38 \text { participants } \\
\text { (surgical group) }\end{array}$ & $\begin{array}{l}\text { Sagittal ramus } \\
\text { osteotomy and/or Le } \\
\text { Fort I osteotomy }\end{array}$ & $\begin{array}{l}\text { Assessments were } \\
\text { performed by } \\
\text { questionnaire before } \\
\text { treatment and } \\
3.1 \pm 1.22 \text { y after } \\
\text { treatment. } \\
\text { Confounding } \\
\text { orthodontic } \\
\text { treatments were } \\
\text { excluded. }\end{array}$ & $\begin{array}{l}\text { The recruited } \\
\text { participants were } \\
\text { assessed before preop } \\
\text { orthodontic treatment } \\
\text { and after postop } \\
\text { orthodontic treatment. }\end{array}$ & $\begin{array}{l}\text { The last questionnaire } \\
\text { was completed } \\
3.1 \pm 1.22 \text { y after } \\
\text { active treatment. }\end{array}$ \\
\hline \multirow{2}{*}{$\begin{array}{l}\text { Nicodemo } \\
\text { et al. }{ }^{17}\end{array}$} & Risk rating & High & Medium & Low & Medium & High & Low \\
\hline & $\begin{array}{l}\text { Rationale } \\
\text { for rating }\end{array}$ & $\begin{array}{l}\text { Only patients with } \\
\text { Angle's class III } \\
\text { malocclusion who } \\
\text { required surgical } \\
\text { treatment and had } \\
\text { undergone preop }\end{array}$ & 29 participants & $\begin{array}{l}\text { Bimaxillary } \\
\text { osteotomy and } \\
\text { monomaxillary } \\
\text { osteotomy } \\
\text { techniques. }\end{array}$ & $\begin{array}{l}\text { The validated } \\
\text { Brazilian SF-36 } \\
\text { questionnaire was } \\
\text { used for the preop } \\
\text { assessment when } \\
\text { the participants }\end{array}$ & $\begin{array}{l}\text { The participants } \\
\text { were wearing } \\
\text { orthodontic } \\
\text { appliances, so the } \\
\text { outcomes may not } \\
\text { have been accurate. }\end{array}$ & $\begin{array}{l}\text { The last } \\
\text { questionnaire was } \\
\text { completed } 6 \text { months } \\
\text { after treatment. }\end{array}$ \\
\hline
\end{tabular}

This article is protected by copyright. All rights reserved 
orthodontic

treatment were

recruited.

\begin{tabular}{|c|c|c|c|}
\hline $\begin{array}{l}\text { Silva et } \\
\text { al. }^{19}\end{array}$ & $\begin{array}{l}\text { Risk } \\
\text { rating }\end{array}$ & Low & High \\
\hline & $\begin{array}{l}\text { Rationale } \\
\text { for rating }\end{array}$ & $\begin{array}{l}\text { Patients with } \\
\text { dentofacial } \\
\text { deformities who } \\
\text { required } \\
\text { orthognathic } \\
\text { surgery were } \\
\text { recruited. }\end{array}$ & 15 participants \\
\hline Lee et al. ${ }^{12}$ & $\begin{array}{l}\text { Risk } \\
\text { rating }\end{array}$ & High & Medium \\
\hline & $\begin{array}{l}\text { Rationale } \\
\text { for rating }\end{array}$ & $\begin{array}{l}\text { Only patients } \\
\text { undergoing } \\
\text { bimaxillary } \\
\text { orthognathic } \\
\text { surgery were }\end{array}$ & 36 participants \\
\hline
\end{tabular}

were undergoing

orthodontic

treatment (which

may have affected

the accuracy of the

assessments) and

was administered 6

months after

surgery.

Low

High

High

Low

Maxillary
advancement or
mandibular setback
or both (bimaxillary
surgery).

The validity of the

Whether the

participants

underwent

orthodontic

treatment was not

mentioned.

High

Medium

High

Only bimaxillary
osteotomy, so the
results may not have
been applicable to
patients undergoing
monomaxillary
surgery.

Data were collected

by the SF-36,

OHIP-14, and

OQLQ-22 during

recruitment (which

was after the

completion of preop
The last

questionnaire was

completed 6 months

after treatment.

Low

The last

questionnaire was

completed 6 months

after treatment. 


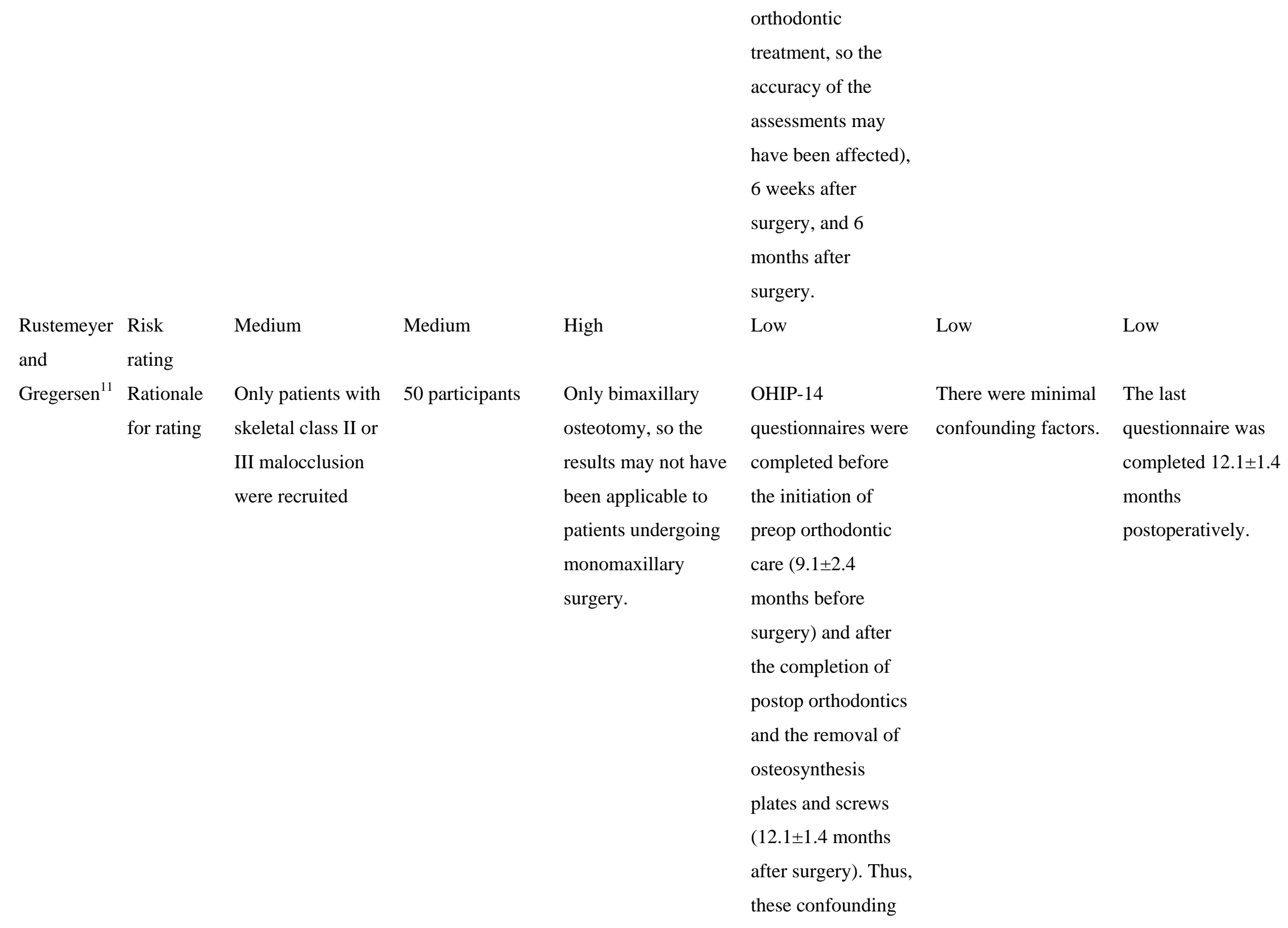

This article is protected by copyright. All rights reserved 


\begin{tabular}{|c|c|c|c|c|c|c|c|}
\hline \multirow{3}{*}{$\begin{array}{l}\text { Murphy et } \\
\text { al. }^{14}\end{array}$} & \multirow{2}{*}{$\begin{array}{l}\text { Risk } \\
\text { rating } \\
\text { Rationale } \\
\text { for rating }\end{array}$} & \multirow[b]{2}{*}{ Low } & \multirow[b]{2}{*}{ Medium } & \multirow[b]{2}{*}{ Low } & \multicolumn{3}{|l|}{$\begin{array}{l}\text { factors were } \\
\text { excluded, which } \\
\text { minimized the risk } \\
\text { of this bias. }\end{array}$} \\
\hline & & & & & Medium & High & Low \\
\hline & $\begin{array}{l}\text { Rationale } \\
\text { for rating }\end{array}$ & $\begin{array}{l}\text { Patients with } \\
\text { maxilla and/or } \\
\text { mandibular } \\
\text { congenital } \\
\text { deformities were } \\
\text { recruited. The } \\
\text { dentofacial } \\
\text { deformities were } \\
\text { not syndromic. }\end{array}$ & 52 participants & $\begin{array}{l}\text { Bimaxillary or } \\
\text { monomaxillary } \\
\text { surgery. }\end{array}$ & $\begin{array}{l}\text { Data were collected } \\
\text { with the OQLQ-22, } \\
\text { VAS, and GTS } \\
\text { during the preop } \\
\text { orthodontic phase of } \\
\text { treatment (which } \\
\text { may have affected } \\
\text { accuracy of the } \\
\text { assessments) and } 6 \\
\text { months after } \\
\text { surgical treatment. }\end{array}$ & $\begin{array}{l}\text { Participants were } \\
\text { wearing orthodontic } \\
\text { appliances, so the } \\
\text { outcomes may not } \\
\text { have been accurate. }\end{array}$ & $\begin{array}{l}\text { The last } \\
\text { questionnaire was } \\
\text { completed } 6 \text { months } \\
\text { after treatment. }\end{array}$ \\
\hline $\begin{array}{l}\text { Soh and } \\
\text { Narayanan }\end{array}$ & $\begin{array}{l}\text { Risk } \\
\text { rating }\end{array}$ & Low & Medium & Low & Medium & High & Low \\
\hline 22 & $\begin{array}{l}\text { Rationale } \\
\text { for rating }\end{array}$ & $\begin{array}{l}\text { Patients with } \\
\text { dentofacial } \\
\text { deformities who } \\
\text { were undergoing } \\
\text { orthognathic } \\
\text { surgery were } \\
\text { recruited. }\end{array}$ & 66 participants & $\begin{array}{l}\text { Bimaxillary or } \\
\text { monomaxillary } \\
\text { surgery }\end{array}$ & $\begin{array}{l}\text { Questionnaires were } \\
\text { completed by } \\
\text { participants during } \\
\text { the preop } \\
\text { orthodontic } \\
\text { treatment phase } \\
\text { (which may have } \\
\text { affected the }\end{array}$ & $\begin{array}{l}\text { Participants were } \\
\text { wearing orthodontic } \\
\text { appliances during } \\
\text { the preop } \\
\text { assessment, so the } \\
\text { outcomes may not } \\
\text { have been accurate. }\end{array}$ & $\begin{array}{l}\text { The last } \\
\text { questionnaire was } \\
\text { completed at least } 6 \\
\text { months after } \\
\text { treatment. }\end{array}$ \\
\hline
\end{tabular}

This article is protected by copyright. All rights reserved 


\begin{tabular}{|c|c|c|c|c|c|c|c|}
\hline & & & & & $\begin{array}{l}\text { accuracy of the } \\
\text { assessments) and at } \\
\text { least } 6 \text { months post- } \\
\text { surgery. }\end{array}$ & & \\
\hline \multirow[t]{2}{*}{$\begin{array}{l}\text { Modig et } \\
\text { al. }^{20}\end{array}$} & $\begin{array}{l}\text { Risk } \\
\text { rating }\end{array}$ & Low & Medium & Low & High & High & Low \\
\hline & $\begin{array}{l}\text { Rationale } \\
\text { for rating }\end{array}$ & $\begin{array}{l}\text { Healthy patients } \\
\text { with maxillary } \\
\text { and mandibular } \\
\text { dentofacial } \\
\text { deformities who } \\
\text { required surgical- } \\
\text { orthodontic } \\
\text { treatment were } \\
\text { recruited. }\end{array}$ & 32 participants & $\begin{array}{l}\text { Bimaxillary or } \\
\text { monomaxillary } \\
\text { surgery }\end{array}$ & $\begin{array}{l}\text { The investigator- } \\
\text { created questionnaires } \\
1 \text { and } 2 \text { (used before } \\
\text { and after treatment, } \\
\text { respectively) have not } \\
\text { been validated. } \\
\text { The exact timing of } \\
\text { the preop } \\
\text { questionnaire was not } \\
\text { mentioned. }\end{array}$ & $\begin{array}{l}\text { It is unclear whether } \\
\text { the participants were } \\
\text { assessed while } \\
\text { undergoing } \\
\text { orthodontic } \\
\text { treatment. }\end{array}$ & $\begin{array}{l}\text { The last } \\
\text { questionnaires were } \\
\text { completed at least } 3 \\
\text { y after treatment. }\end{array}$ \\
\hline \multirow[t]{2}{*}{$\begin{array}{l}\text { Sadek and } \\
\text { Salem }^{23}\end{array}$} & $\begin{array}{l}\text { Risk } \\
\text { rating }\end{array}$ & Low & Low & High & High & High & Low \\
\hline & $\begin{array}{l}\text { Rationale } \\
\text { for rating }\end{array}$ & $\begin{array}{l}\text { Patients with } \\
\text { dentofacial } \\
\text { deformities who } \\
\text { required } \\
\text { orthognathic } \\
\text { surgery were } \\
\text { recruited. }\end{array}$ & 120 participants & $\begin{array}{l}\text { Types of surgery not } \\
\text { mentioned }\end{array}$ & $\begin{array}{l}\text { The questionnaire } \\
\text { assessing } \\
\text { motivation for } \\
\text { surgery and } \\
\text { satisfaction with } \\
\text { treatment has not } \\
\text { been validated. The } \\
\text { exact timing of the } \\
\text { preop questionnaire }\end{array}$ & $\begin{array}{l}\text { It is unclear whether } \\
\text { the participants were } \\
\text { assessed while } \\
\text { undergoing } \\
\text { orthodontic } \\
\text { treatment. }\end{array}$ & $\begin{array}{l}\text { The last } \\
\text { questionnaires were } \\
\text { completed 6-12 } \\
\text { months after surgery. }\end{array}$ \\
\hline
\end{tabular}

This article is protected by copyright. All rights reserved 
was not mentioned.

Timing data are presented as means \pm standard deviations or ranges.

Abbreviations: GTS, global transition scale; NR, not reported; OHIP-14, Oral Health Impact Profile-14; OQLQ-22, Orthognathic Quality of Life Questionnaire-22; preop, preoperative; postop, postoperative; SF-36, Short Form Health Survey; VAS, visual analogue scale

This article is protected by copyright. All rights reserved 
Table 3. Physical function and limitation before and after orthognathic surgery

\begin{tabular}{lllllll}
\hline Study & Domain/ & Pre-op & Post-op final & Mean & Effect & P value \\
& question & outcome & outcome (SD & difference & size & \\
& & $($ SD or & or 95\% CI) & (SD or & & \\
& & & $95 \%$ CI $)$ & & & \\
& & & &
\end{tabular}

\section{Assessed by the OHIP-14 questionnaire}

$\begin{array}{llllll}\text { Göelzer et } & 1.51(1.13) & 0.58(0.63) & 0.93(1.02) & 0.65 & <0.001\end{array}$

al. $^{15}$

Choi et al. ${ }^{13}$

$2.41(10.08) \quad 1.03(1.49) \quad-1.38(1.76) \quad-0.75 \quad<0.001$

Silvola et

$1.7-0.8$

$-0.9$

$<0.05$

al. $^{16}$

Lee et al. ${ }^{12}$

$2.47(1.98) \quad 1.56(1.48) \quad 0.92(1.89)$

0.46

0.008

Rustemeyer

Question

$0.8(0.46-$

$0.64(0.39-\quad-0.16(-0.51$

and

1.14)

0.89)

$-0.18)$

Gregersen $^{11}$

Question 2

$0.32(0.09$

$0.60(0.29-$

$0.29(-0.01-$

$-0.55)$

$0.91)$

$0.57)$

\section{Assessed by the SF-36 questionnaire}

$\begin{array}{lccccc}\text { Choi et al. }^{13} & 96.88 & 96.25 & -0.63 & -0.13 & 0.620 \\ & (4.88) & (8.98) & (10.38) & & \\ \text { Khadka et } & 95.63 & 95.72 & 0.09 & & \\ \text { al. }^{18} & (5.07) & (5.10) & (0.67) & & \\ \text { Lee et al. }^{12} & 97.22 & 96.67 & 0.56 & 0.12 & 0.681 \\ & (4.54) & (5.73) & (5.32) & & \end{array}$

Assessed by the OQLQ-22 questionnaire

Choi et al. ${ }^{13}$

$9.31(4.93) \quad 2.81(4.38)$

$-6.50$

$-1.32$

$<0.001$

(4.72)

Khadka et

$9.12(3.72) \quad 3.29(2.45) \quad 5.83(4.41)$

al. $^{18}$

Lee et al. ${ }^{12}$

$9.25(5.06)$

$4.94(3.41)$

$4.31(5.05)$

0.85

$<0.001$

Murphy et

$7.46(5.99)$

$5.69(5.77)$

$1.77(6.00)$

0.4

0.0384

al. $^{14}$

Soh and

$8.67(3.83) \quad 7.89(3.52)$

$-0.18$

0.071

Narayanan $^{21}$ 


\section{Assessed by other instruments/questionnaires}

\begin{tabular}{|c|c|c|c|}
\hline Study & Instruments & Pre-op outcome & Post-op final outcome \\
\hline Silva et al. ${ }^{19}$ & $\begin{array}{l}\text { Questionnaires used } \\
\text { by authors } \\
\text { WHOOQL-Brief }\end{array}$ & $\begin{array}{l}40 \% \text { of participants } \\
\text { reported "bite problems" }\end{array}$ & $\begin{array}{l}86.67 \% \text { of participants } \\
\text { reported high physical } \\
\text { aspect }\end{array}$ \\
\hline Modig et al. ${ }^{20}$ & $\begin{array}{l}\text { Questionnaires used } \\
\text { by authors } \\
\text { Visual Analogue } \\
\text { Scale } \\
\text { OHIP-49 } \\
\text { Telephone interview }\end{array}$ & $\begin{array}{l}28.55 \% \text { of participants } \\
\text { wanted better chewing } \\
\text { ability } \\
4.13 \% \text { of participants } \\
\text { wanted better } \\
\text { pronunciation of word }\end{array}$ & $\begin{array}{l}91 \% \text { of participants } \\
\text { reported better chewing } \\
\text { ability } \\
19 \% \text { of participants } \\
\text { reported better } \\
\text { pronunciation of word }\end{array}$ \\
\hline
\end{tabular}

This article is protected by copyright. All rights reserved 
Table 4. Physical Pain Before and After Orthognathic Surgery

\begin{tabular}{|c|c|c|c|c|c|c|}
\hline Study & Score & $\begin{array}{l}\text { Preop } \\
\text { outcome } \\
\text { (SD or } 95 \% \\
\text { CI) }\end{array}$ & $\begin{array}{l}\text { Postop final } \\
\text { outcome } \\
\text { (SD or } 95 \% \\
\text { CI) }\end{array}$ & $\begin{array}{l}\text { Mean } \\
\text { difference } \\
\text { (SD or } 95 \% \\
\text { CI) }\end{array}$ & $\begin{array}{l}\text { Effect } \\
\text { size }\end{array}$ & $P$ value \\
\hline
\end{tabular}

\section{OHIP-14}

Göelzer et

Physical $2.10(2.19)$

$0.72(0.83)$

NR

$-0.74$

$\leq 0.001$

al. (2014) pain

Choi et al. Physical

$3.06(1.87)$

$0.84(1.35)$

$-2.22(1.60)$

$-1.19$

$<0.001$

(2010)

pain

Silvola et al. Physical 4.6

1.8

$-2.9$

NR

$<0.05$

(2014)

pain

Lee et al. Physical

$3.11(1.79)$

$2.00(1.74)$

$-1.11(1.79)$

$-0.62$

0.001

(2008)

pain

Rustemeyer Question

0.98 (0.63 to

0.97 (0.71 to

$-0.08(-0.41 \quad$ NR

0.904

and

$3^{\mathrm{a}}$

1.32)

1.24)

to 0.25 )

Gregersen

Question

0.92 (0.59 to

$0.90(0.55$ to

$-0.02(-0.46$

NR

0.928

(2012)

$4^{\mathrm{b}}$

to 0.42 )

Rustemeyer Physical NR

NR

NR

NR

NS

et al. (21) pain

\section{SF-36}

Choi et al.

Bodily

$79.34(18.68)$

$86.97(15.72)$

$7.63(23.42)$

0.41

0.054

(2010)

pain

Khadka et

Bodily

$93.97(9.33)$

$94.11(9.65)$

$0.13(3.46)$

NR

NR

al. (2011) pain

Lee et al. Bodily

$83.14(18.92) \quad 85.78(17.41) \quad 2.64(3.79)$

0.14

0.681

(2008)

pain

a question 3 refers to mouth pain

${ }^{\mathrm{b}}$ question 4 refers to having discomfort while eating food

For the OHIP-14, lower scores represent more favourable responses (better QOL). In contrast, for the SF-36, lower scores represent less favourable responses (worse QOL).

Abbreviations: CI, confidence interval; NR, not reported; NS, not significant; OHIP-14, Oral Health Impact Profile-14; preop, preoperative; postop, postoperative; SD, standard deviation; SF-36, Short Form Health Survey

This article is protected by copyright. All rights reserved 
Table 5. Psychological Well-being and Self-esteem Before and After Orthognathic Surgery

\begin{tabular}{lllllll}
\hline Study & Psychological & Preop & Postop final & Mean & Effect & P \\
domain or & outcome & outcome & difference & size & value \\
question & (SD or & (SD or 95\% & (SD or & & \\
& & $95 \%$ CI $)$ & CI) & $95 \%$ CI $)$ & &
\end{tabular}

\section{OHIP-14}

Göelzer et

Psychological 2.68 (1.11)

$0.44(0.73)$

NR

$-0.84 \leq 0.001$

al. (2014) discomfort

Psychological

$2.13(1.02)$

$0.41(0.72)$

NR

$-0.83 \leq 0.001$

disability

Choi et al. Psychological 4.44 (2.00)

$1.44(2.09)$

$-3.00(2.17) \quad-1.50$

$<0.001$

(2010)

discomfort

Psychological 3.94 (2.17)

$1.13(1.76)$

$-2.81(1.67) \quad-1.29$

$<0.001$

disability

Rustemeyer Question 5

1.42 (1.01 to 0.68 ( 0.41 to

$-0.73(-0.29 \quad \mathrm{NR}$

0.022

et al. (21)

0.96)

to -1.18$)$

Question 6

$1.47(0.99$

0.84 ( 0.51 to

$-0.63(-0.14 \quad N R$

0.045

to 1.95 )

1.17)

to -1.11 )

Question $10^{\mathrm{c}}$

$1.26(0.66$

0.47 ( 0.18 to

$-0.78(-0.27 \quad N R$

0.027

to 1.86 )

$0.75)$

to -1.31 )

Silvola et Psychological 3.7

0.9

$-2.8$

NR

$<0.05$

al. (2014) discomfort

Psychological 2.8

0.5

$-2.3$

NR

$<0.05$

disability

Lee et al

Psychological 4.42 (1.98)

$2.78(2.31)$

$-1.64(2.18) \quad-0.83$

$<0.001$

(2008)

discomfort

Psychological 3.94 (2.29)

$2.39(2.03)$

$-1.56(1.81) \quad-0.68$

$<0.001$

disability

Rustemeyer Question 5

$1.30(0.91$

0.75 (0.46 to

$-0.65(-1.10 \quad N R$

0.017

and

to 1.68$)$

1.04)

to -0.20 )

Gregersen Question 6 ${ }^{\mathrm{b}}$

$1.18(0.81$

0.67 (0.39 to

$-0.52(-0.81 \quad N R$

$<0.001$

(2012)

to 1.55$)$

$0.95)$

to -0.22 ) 


$\begin{array}{llllll}\text { Question } 9^{\mathrm{d}} & 1.02(0.66 & 0.58(0.31 \text { to } & -0.44(-0.73 & \mathrm{NR} & 0.003 \\ & \text { to } 1.38) & 0.84) & \text { to }-0.15) & & \\ \text { Question } 10^{\mathrm{c}} & 1.44(1.03 & 0.50(0.25 \text { to } & -1.02(-1.38 & \mathrm{NR} & <0.001 \\ & \text { to } 1.84) & 0.74) & \text { to }-0.65) & & \end{array}$

\section{SF-36}

Choi et al.

77.07

$88.54(26.25) \quad 11.47(42.86) \quad 0.33$

0.131

(2010)

emotional

(34.34)

Mental health 68.13

$73.88(14.51) \quad 5.75(18.98) \quad 0.36$

0.089

(15.82)

$\begin{array}{lll}\text { Khadka et } & \text { Role - } & 78.18\end{array}$

(32.38)

al. (2011)

emotional

66.94

$67.89(14.94) \quad 0.94(2.65) \quad$ NR

NR

Nicodemo

$79.5(8.9)^{\mathrm{e}}$

$71.7(10.6)^{\mathrm{e}} \quad \mathrm{NR}$

NR

$0.019^{\mathrm{f}}$

et al.

well-being

(2008) (males)

Emotional

$58.4(8.4)^{\mathrm{e}}$

$87.5(7.4)^{\mathrm{e}} \quad \mathrm{NR}$

NR

well-being

(females)

Mental health NR

NR NR NR NS

Lee et al.

Role -

79.63

91.67 (16.67) $12.04(31.02) \quad 0.37$

0.029

(2008)

emotional

Mental health 70.11

$70.78(15.05) \quad 0.67(15.40) \quad 0.04$

0.925

(15.64)

OQLQ-22

Choi et al. Awareness of 7.91 (4.26)

$\begin{array}{llll}5.44(4.31) & -2.47(5.14) & -0.58 & 0.012\end{array}$

(2010)

dentofacial

aesthetics

Khadka et $\quad$ Awareness of $7.15(4.47) \quad 3.64(2.63) \quad 3.5(5.6) \quad$ NR $\quad$ NR

al. (2011) dentofacial

aesthetics

Lee et al. Awareness of 7.58 (4.12)

$6.72(4.53) \quad-0.86(3.16) \quad-0.21$

0.101

(2008)

dentofacial 
aesthetics

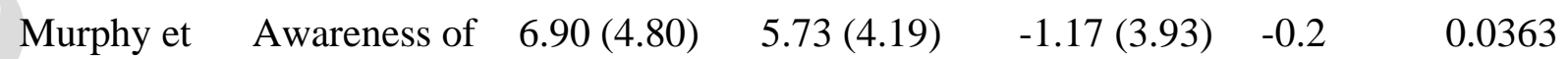

al. (2011) dentofacial

aesthetics

$\begin{array}{lllllll}\text { Soh and } & \text { Awareness of } & 10.52(2.85) & 6.20(2.40) & \text { NR } & -1.52 & 0.0001 \\ \text { Narayanan } & \text { dentofacial } & & & & \\ (22) & \text { aesthetics } & & & & \end{array}$

question 5 refers to feelings of self-consciousness

${ }^{\mathrm{b}}$ question 6 refers to feeling tense

${ }^{c}$ question 10 refers to feelings of embarrassment

${ }^{\mathrm{d}}$ question 9 refers to difficulty relaxing

${ }^{\mathrm{e}}$ standard error

${ }^{\mathrm{f}} \mathrm{p}$ value for the effects of the interaction between gender and time period (preoperative and postoperative) on emotional well-being. The Bonferroni tests showed that emotional wellbeing improved significantly only in females after surgery.

For the OHIP-14 and OQLQ-22, lower scores represent more favourable responses (better QOL). In contrast, for the SF-36, lower scores represent less favourable responses (worse QOL).

Abbreviations: CI, confidence interval; NR, not reported; NS, not significant; OHIP-14, Oral Health Impact Profile-14; OQLQ-22, Orthognathic Quality of Life Questionnaire-22; preop, preoperative; postop, postoperative; SD, standard deviation; SF-36, Short Form Health Survey

This article is protected by copyright. All rights reserved 
Table 6. Self-perception with Regards to Facial Aesthetics Before and After Orthognathic Surgery

\begin{tabular}{|c|c|c|c|c|c|c|}
\hline Study & $\begin{array}{l}\text { Domain or } \\
\text { assessment } \\
\text { method }\end{array}$ & $\begin{array}{l}\text { Preop } \\
\text { outcome } \\
\text { (SD or } \\
95 \% \text { CI) }\end{array}$ & $\begin{array}{l}\text { Postop final } \\
\text { outcome (SD } \\
\text { or } 95 \% \text { CI) }\end{array}$ & $\begin{array}{l}\text { Mean } \\
\text { difference } \\
\text { (SD or } \\
95 \% \mathrm{CI} \text { ) }\end{array}$ & $\begin{array}{l}\text { Effect } \\
\text { size }\end{array}$ & $\begin{array}{l}\mathbf{P} \\
\text { value }\end{array}$ \\
\hline \multicolumn{7}{|l|}{ OQLQ-22 } \\
\hline $\begin{array}{l}\text { Choi et al. } \\
(2010)\end{array}$ & $\begin{array}{l}\text { Facial } \\
\text { aesthetics }\end{array}$ & $\begin{array}{l}13.63 \\
(4.76)\end{array}$ & $6.41(3.56)$ & $\begin{array}{l}-7.22 \\
(5.12)\end{array}$ & -1.52 & $<0.001$ \\
\hline $\begin{array}{l}\text { Khadka et al. } \\
\text { (2011) }\end{array}$ & $\begin{array}{l}\text { Facial } \\
\text { aesthetics }\end{array}$ & $\begin{array}{l}11.97 \\
(6.11)\end{array}$ & $4.46(4.06)$ & $7.5(7.37)$ & NR & NR \\
\hline $\begin{array}{l}\text { Lee et al. } \\
\text { (2008) }\end{array}$ & $\begin{array}{l}\text { Facial } \\
\text { aesthetics }\end{array}$ & $\begin{array}{l}13.31 \\
(4.91)\end{array}$ & $8.36(4.02)$ & $\begin{array}{l}-4.94 \\
(4.63)\end{array}$ & -1.01 & $<0.001$ \\
\hline $\begin{array}{l}\text { Murphy et al. } \\
\text { (2011) }\end{array}$ & $\begin{array}{l}\text { Facial } \\
\text { aesthetics }\end{array}$ & $\begin{array}{l}12.21 \\
(5.87)\end{array}$ & $7.00(5.64)$ & $\begin{array}{l}-5.21 \\
(6.19)\end{array}$ & -0.9 & 0.0001 \\
\hline $\begin{array}{l}\text { Soh and } \\
\text { Narayanan } \\
\text { (22) }\end{array}$ & $\begin{array}{l}\text { Facial } \\
\text { aesthetics }\end{array}$ & $\begin{array}{l}15.80 \\
(2.98)\end{array}$ & 6.89 (2.19) & NR & -2.98 & 0.0001 \\
\hline Other Assessı & nent Methods & & & & & \\
\hline $\begin{array}{l}\text { Silvola et al. } \\
(2014)\end{array}$ & $\begin{array}{l}\text { VAS of } \\
\text { aesthetic } \\
\text { satisfaction }\end{array}$ & 61.4 & 18.5 & -42.9 & NR & $<0.05$ \\
\hline $\begin{array}{l}\text { Alves e Silva } \\
\text { et al. (19) }\end{array}$ & $\begin{array}{l}\text { Questionnaires } \\
\text { created by } \\
\text { authors }\end{array}$ & $\begin{array}{l}53.3 \% \text { of } \\
\text { participants } \\
\text { were "a } \\
\text { little" } \\
\text { satisfied } \\
\text { with their } \\
\text { appearance, } \\
\text { and } 40 \% \\
\text { were }\end{array}$ & $\begin{array}{l}\text { Of the } \\
\text { participants } \\
\text { who were "a } \\
\text { little" satisfied } \\
\text { preoperatively, } \\
33 \% \text { became } \\
\text { "satisfied", and } \\
20 \% \text { became } \\
\text { "very }\end{array}$ & NR & NR & NR \\
\hline
\end{tabular}


"satisfied" satisfied"

with their

appearance

\begin{tabular}{|c|c|c|c|c|c|}
\hline Rustemeyer & Additional & 3.12 (2.89 to & $1.74(1.45$ to & $-1.38(-$ & $<0.001$ \\
\hline and & question about & 3.34) & 2.02) & 1.03 to - & \\
\hline Gregersen & dissatisfaction & & & 1.74) & \\
\hline (2012) & with facial & & & & \\
\hline
\end{tabular}

Modig et al. Investigator- In $30 \%$ of $28 \%$ of $\quad$ NR $\quad$ NR NR

(20) created participants, participants

questionnaires, the reason for reported

the VAS, the surgery was improvements

OHIP-49, an in their

telephone anticipated appearance

interviews change in (by the VAS)

appearance;

$43 \%$ of

participants

paid

excessive

attention to

their

appearance

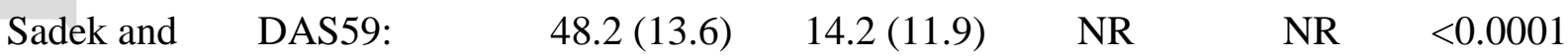

Salem (23) Assessments of

general self-

consciousness

regarding

appearance

$\begin{array}{llllll}\text { DAS59: } & 29.5(15.6) & 12.3(10.9) & \text { NR } & \text { NR } & <0.0001\end{array}$

Assessments of

social self-

consciousness 
regarding

appearance

DAS59: $\quad 17.2(4.1) \quad 9.7(3.5) \quad$ NR $\quad$ NR $\quad<0.0001$

Assessments of

negative self-

conceptions

For the OQLQ-22, OHIP-49, DAS59, and VAS, lower scores represent more favourable responses (better QOL).

Abbreviations: CI, confidence interval; DAS59, Derriford Appearance Scale 59; NR, not reported; NS, not significant; OHIP-49, Oral Health Impact Profile-49; OQLQ-22, Orthognathic Quality of Life Questionnaire-22; preop, preoperative; postop, postoperative; SD, standard deviation; SF-36, Short Form Health Survey; VAS, visual analogue scale 
Table 7. Social Functioning and Relationships Before and After Orthognathic Surgery

\begin{tabular}{llllll}
\hline Study & Domain or & Preop & Postop & Mean & Effect P value \\
Question & outcome & final & difference & size \\
& (SD or & outcome & (SD or & \\
& $95 \%$ CI $)$ & (SD or & $95 \%$ CI) & \\
& & $95 \%$ CI $)$ & &
\end{tabular}

\section{OHIP-14}

Göelzer et Social

1.55 (1.10)

$0.24(0.60)$

NR

$-0.77 \leq 0.001$

al. (2014) disability

Choi et al. Social

$1.78(1.52)$

$0.63(1.26)$

$-1.16$

$-0.76<0.001$

(2010)

disability

Rustemeyer Question 11

$1.21(0.67$

$0.52(0.24$

(1.44)

et al. (21)

to 1.75$)$

to 0.81 )

$-0.68(-0.18$ NR

0.043

Question $12^{\mathrm{b}}$

NR

NR

to -1.17 )

Silvola et al. Social

1.9

0.2

NR

NR NS

(2014)

disability

Lee et al. Social

1.69 (1.67)

$1.00(1.76)$

$-0.69$

$-0.41 \quad 0.011$

(2008)

disability

Rustemeyer Question 11

$0.70(0.41$

$0.38(0.17$

(1.49)

and

to 0.99 )

to 0.58 )

$-0.26(-0.52$ NR

0.019

Gregersen Question 12

$0.40(0.14$

$0.42(0.17$

to -0.01 )

(2012)

to 0.66 )

to 0.66 )

$0.22(-0.29 \quad \mathrm{NR}$

0.456

SF-36

Choi et al. Social

\subsection{4}

91.02

8.58

$0.44 \quad 0.063$

(2010)

functioning

(19.54)

(12.39)

(22.78)

Khadka et Social

82.27

82.61

0.34 (2.04)

NR

NR

al. (2011)

functioning

(18.73)

(18.08)

Nicodemo Social

$70.8(11.9)^{\mathrm{c}}$

$77.2(10.4)^{\mathrm{c}} \quad \mathrm{NR}$

NR $\quad 0.002^{\mathrm{d}}$

et al. (2008) functioning

(males,

bimaxillary

surgery) 
Social

$44.2(10.7)^{\mathrm{c}} \quad 80.2(14.1)^{\mathrm{c}} \quad \mathrm{NR}$

NR

functioning

(females,

bimaxillary

surgery)

Social

$69.9(9.8)^{\mathrm{c}}$

$80.4(8.6)^{\mathrm{c}}$

NR

NR

functioning

(males,

monomaxillary

surgery)

Social

$60.0(6.3)^{\mathrm{c}}$

$89.9(4.7)^{\mathrm{c}} \quad \mathrm{NR}$

NR

functioning

(females,

monomaxillary

surgery)

Lee et al. Social

82.99

89.24

6.25

0.33

0.062

(2008)

functioning

(19.17)

(16.68)

(19.48)

\section{OQLQ-22}

Choi et al. Social

$13.88(8.12) \quad 6.03(7.18)$

$-7.84$

$-0.97<0.001$

(2010)

Khadka et Social

$12.57(9.56) \quad 4.05(4.25)$

al. (2011)

Lee et al. Social

$12.39(8.08)$

$8.08(6.47)$

$(10.4)$

(2008)

Murphy et Social

$10.42(8.33) \quad 7.19(8.32)$

al. (2011)

Soh and

Social

$22.26(5.52) \quad 14.98(4.48)$

Narayanan

(22)

${ }^{\mathrm{a}}$ question 11 refers to irritability when interacting with others

${ }^{\mathrm{b}}$ question 12 refers to difficulty performing typical job-related tasks

${ }^{c}$ standard error

${ }^{\mathrm{d}} \mathrm{p}$ value for the effects of the interaction among gender, time period (preoperative and postoperative), and type of surgery on social functioning. The Bonferroni tests showed that 
social functioning improved in both genders, as well as in patients undergoing either type of surgery, after surgery.

For the OHIP-14 and OQLQ-22, lower scores represent more favourable responses (better QOL). In contrast, for the SF-36, lower scores represent less favourable responses (worse QOL).

Abbreviations: CI, confidence interval; NR, not reported; NS, not significant; OHIP-14, Oral Health Impact Profile-14; OQLQ-22, Orthognathic Quality of Life Questionnaire-22; preop, preoperative; postop, postoperative; SD, standard deviation; SF-36, Short Form Health Survey 
Figure 1. Flow diagram of the study selection process

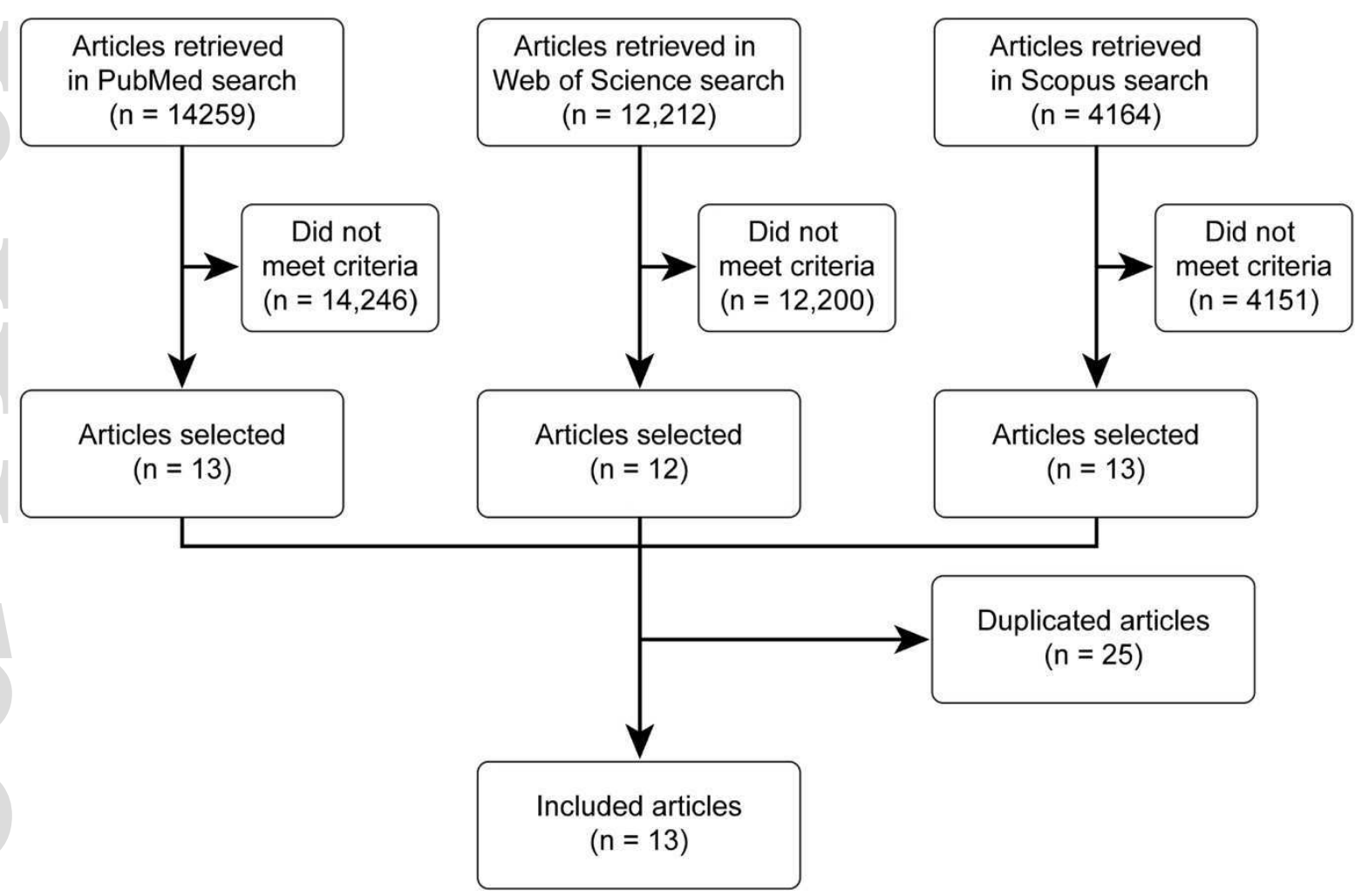

This article is protected by copyright. All rights reserved 